\title{
Influence of DEM resolution on modelling hydrological connectivity in a complex agricultural catchment with woody crops
}

\author{
M. López-Vicente*, S. Álvarez \\ Dept. of Soil and Water, Experimental Station of Aula Dei, EEAD-CSIC. Avda. Montañana 1005, 50059, \\ Zaragoza, Spain \\ * Corresponding author. Tel.: +34 9768161 24; E-mail addresses: mvicente@eead.csic.es, \\ mlopezvicente@gmail.com (Manuel López-Vicente).
}

Received 29 May 2017; Revised 1 December 2017; Accepted 11 December 2017

Published online (18 December 2017) in Wiley Online Library:

http://onlinelibrary.wiley.com/doi/10.1002/esp.4321/full

DOI: $10.1002 /$ esp.4321

\section{Earth Surface Processes and Landforms}

ABSTRACT: Digital elevation model (DEM) resolution influences hydrological simulation. However, its influence when modelling hydrological connectivity $(\mathrm{HC})$ in woody crops remains to be seen. We assessed surface topography, microtopography and HC in an agricultural subcatchment (27.4 ha) using six photogrammetry-derived DEMs with $0.03,0.05,0.1,0.2,0.5$ and $1 \mathrm{~m}$ cell sizes. Land uses included vineyards, olive groves, cereal fields, and forestry patches. We ran an updated version of Borselli's HC index (IC) using the D-Infinity approach. We assessed $\mathrm{HC}$ in woody crops at high spatial resolution for the first time. After analysing the differences in the contributing area, the flow width, the soil roughness, the convergence index and the IC (normalised and non-normalised) at different scales (hillslope, land uses and compartments, ephemeral gullies, depositional areas and the sub-catchment outlet) and accounting for the field vertical components, we propose an optimum DEM resolution (0.2 m) to improve modelling of structural HC in woody crops. The modelled hydrological features at this threshold resolution matched well with the geomorphic features associated with the short- and medium-term patterns of soil redistribution. Higher DEM resolutions, especially at 
0.03 and $0.05 \mathrm{~m}$, introduced bias in the input data and the $I C$ computations. Finally, we observed good agreement between the outputs at the lowest resolution, $1 \times 1 \mathrm{~m}$, and the long-term soil redistribution patterns (functional connectivity).

KEYWORDS: DEM resolution; soil roughness; hydrological connectivity; vineyard; olive grove

\section{Introduction}

Raster digital elevation model (DEM) resolution is known to have an effect on simulations of hydrological features and topographic parameters such as stream networks, watershed boundaries and sizes, flow accumulation threshold values, network morphology and slope (Vaze et al., 2010; Ariza-Villaverde et al., 2015). The use of different DEMs, at low and high resolution, has serious implications on the predictions derived from hydraulic models, such as flood water levels and inundation maps (Ali et al., 2015). In agricultural catchments, DEM resolutions must be optimised in order to identify critical source areas of diffuse pollution and to capture any microtopographic features acting as topographic barriers or channels which divert runoff away from the hillslope scale flow direction (Thomas et al., 2017). Re-sampling the highest resolution DEM (e.g., LiDAR at $1 \mathrm{~m}$ ) to a lower resolution reduces model accuracy much less than the use of low-resolution DEM (e.g., from satellite imagery, such as ASTER and SRTM). In large areas (greater than $100 \mathrm{~km}^{2}$ ), Ghumman et al. (2017) found similar model efficiencies in the accuracy of rainfall-runoff models using both higher ( 5 or $10 \mathrm{~m}$ ) and lower (30 and $90 \mathrm{~m}$ ) DEM resolutions. However, in small areas (less than $1 \mathrm{~km}^{2}$ ), the extra detail inherent in very high resolution $(10 \mathrm{~cm})$ terrestrial data is valuable when running surface models and analysing flood risk values (Sampson et al., 2012). In agricultural areas, Woodrow et al. (2016) found a significant disagreement in mapped surface drainage patterns at the scale of individual fields in function of DEM resolution over a range of 1 to $10 \mathrm{~m}$.

Despite the importance of DEM resolution in hydrological studies, relatively few publications have only just recently addressed this issue in terms of modelling hydrological connectivity (HC). Habtezion et al. (2016) performed a small experimental field plot to examine the effects of nine DEM resolutions (created by interpolation and based on the same DEM), ranging from 0.02 to $0.8 \mathrm{~m}$, on surface hydrologic characteristics. They found that lower DEM resolutions tended to eliminate topographic features, reduce surface depression storage, and strengthen hydrologic connectivity and surface runoff. Cantreul et al. (2016) compared eight 
different DEM resolutions $(0.12,0.24,0.48,0.72,0.96,2.04,5.04$ and $9.96 \mathrm{~m})$ when calculating the Borselli's index of runoff and sediment connectivity (IC; Borselli et al. (2008) in a 124 ha cultivated catchment in Belgium. These authors found that connectivity increased for a given pixel when its size decreased. They also highlighted that disconnected areas within the landscape were more frequent with the highest DEM resolutions. However, on land surfaces with numerous small-scale depressions, the use of lower resolution DEMs tended to overestimate hydrologic connectivity and simplified hydrographs (Yang and Chu, 2013). So there is a variety of, and sometimes contrasting, conclusions about the effects of DEM resolution and the $\mathrm{HC}$ values for a given site depending on its topographic characteristics. The impact of increased spatial variability in model parameters and their influence on the quality of flow simulations remains unknown (David et al., 2013).

Permanent features in agricultural lands, such as the trunks of woody crops and grooves and rows following straight lines, mainly control overland flow paths, especially in areas with low and moderate slope (López-Vicente et al., 2016a). Woody crops, such as vineyards, almond, olive, orange, coffee, tea, and other fruit groves, as well as forest plantations, are cultivated on a significant percentage of the world's agricultural soil. These perennial crops represent about $16 \%$ of Mediterranean agricultural land $(F A O, 1998)$ and are of a great economic importance (Infante-Amate, 2012). Additionally, the construction of small-scale water diversion and collection infrastructures in agricultural areas may significantly alter hillslope-channel coupling (Callow and Smettem, 2009).

Soil roughness characterization in tilled soils depends on the spatial resolution of the topographic data; whereas, at the same time, soil roughness, overland flow dynamics and functional connectivity evolve differently depending on whether diffuse or concentrated runoff dominates (Peñuela et al., 2016). However, we did not find any studies that investigated the effect of DEM resolution on the magnitude and patterns of modelling HC in woody crops. Therefore, there is a need to bridge the gap between different DEM resolutions and HC values in woody agricultural systems.

DEMs can be derived from several sources, for example, the most commonly used data sources in the past were topographic contour line maps, while modern techniques include remote sensing (reflection radiometer and radar), Light Detection And Ranging (LiDAR) technology, photogrammetric restitution, and most recently Structure-from-Motion (SfM) (Ali et al., 2015; Prosdocimi et al., 2017). These DEMs are characterized by different degrees of precision and accuracy, as well as varying ranges of spatial resolution, time and economic cost. Woodrow et al. (2016) found large disagreements between the field-scale contributing areas mapped from the LiDAR DEM and photogrammetric DEM, with nearly half of the study area 
draining to different field boundaries. Furthermore, differences in derived contributing areas and flow paths between the two techniques increased substantially at higher grid resolutions. Photogrammetric restitution techniques have been known for decades, but the current possibility of digitally analysing hundreds of pictures at very high spatial resolutions (cm or $\mathrm{mm} /$ pixel) has enhanced the technique's use in many scientific disciplines, including vegetation analysis, hydrological and soil erosion studies (Aucelli et al., 2016; Díaz-Vilariño et al., 2016). In areas with low vegetation cover and/or before sprouting in woody crops, the SfM technique provides landform models and point cloud data of similar or slightly inferior quality to those generated by airborne LiDAR but more quickly and at a lower cost.

Hydrological connectivity studies are essential for the effective management of runoff, soil, and critical source areas of nutrients and pollutants in agricultural catchments (Shore et al., 2013). The concept of connectivity helps us to express the complexity of non-linear landscape responses to rainfall inputs in terms of water and sediment yields (Parsons et al., 2015). Several HC indices have been published in the literature over the last decade, such as the Network Index by Lane et al. (2009), and the Relative Surface Connection (RSC) function proposed by Antoine et al. (2009). Sediment cascades have also been explored using graph theory (Heckmann and Schwanghart, 2013), and hydrologic models to make connectivity predictions, such as the Reaney et al.'s (2014) Connectivity of Runoff Model, 2D version. Borselli et al. (2008) developed the index of runoff and sediment connectivity (IC) and successfully tested their approach against field observations in a large catchment in central Italy. For each pixel, this qualitative index $[-\infty,+\infty]$ accounts for the combined effect of the upslope topographic and land-use characteristics and these parameters' values throughout the flow path line a soil particle must travel to reach the nearest defined stream or sink. The IC model's capacity was then demonstrated in different fields and catchments around the world, e.g., the studies by Vigiak et al. (2012) in Australia, Cavalli et al. (2013) in Italy, D'Haen et al. (2013) in Turkey, Gay et al. (2016) in France, Cantreul et al. (2016) in Belgium, and Chartin et al. (2017) in Japan. Several studies in southern (Sougnez et al., 2011; Martínez-Murillo and López-Vicente, 2017) and north-eastern Spain (López-Vicente et al., 2013a, 2017a; Foerster et al., 2014) proved its capacity to map runoff and sediment connectivity.

There is a good agreement between experts that landscape hydrological pathways and connectivity to surface waters are mainly controlled by physical factors, whereas uncertainties are generally associated with the heterogeneity and variability of unique catchments (Page et al., 2012). We hypothesise that both the $I C$ and some independent microtopographic parameters, such as soil roughness $(S R)$ and the convergence index $(C I)$, in woody crops 
depend on the spatial resolution of the DEM used. Therefore we: (i) compared the pattern of high/low flow accumulation at different resolutions to actual flow paths linked to runoff events of different magnitude/intensity; and (ii) suggested an optimum resolution for computing $I C$ in order to represent connectivity at these intensities. To achieve these goals we: (i) selected a complex agro-ecosystem with different crops (cereal, vineyards and olive groves) and tillage practices; (ii) ran an updated version of the $I C$ model at six spatial resolutions $(0.03$, $0.05,0.1,0.2,0.5$ and $1 \mathrm{~m}$ ); (iii) performed a sensitivity analysis on the resulting hydrological features, before and after value normalisation, at short (field) and medium (agro-ecosystem) scales; and (iv) validated the results by means of benchmarks and field measurements. The different compartments of the woody crops, such as rows, inter-row areas and corridors, make this agricultural system an ideal frame to test our hypothesis. The results of this study aim to fill a gap in the literature concerning hydrological studies at field and hillslope scales and will help improve hydrological connectivity indices and modelling approaches for runoff events of different magnitude/intensity.

\section{Materials and methods}

\section{Study area}

A Mediterranean agricultural system located in the Ebro river basin (NE Spain; $42^{\circ} 02^{\prime} 00^{\prime \prime} \mathrm{N}$; $0^{\circ} 04^{\prime} 12^{\prime \prime}$ E) was selected for this study (Figure 1). This sub-catchment, known as BA hereafter, is near the town of Barbastro and occupies an area of 27.4 ha. An ephemeral gully drains away to the outlet which is situated near the northern boundary. In a previous, lowresolution study (5 x 5 m), López-Vicente and Navas (2015) distinguished two sub-basins, identified as SB-1 and SB-2. The authors reported high hydrological connectivity and continuous flow path lines in SB-1, in contrast to low connectivity and highly discontinuous flow path lines in SB-2. Field observation of rills indicated that SB-2 acts as tributary of SB-1 at least during high intensity rainfall and runoff events. The topography is hilly with a mean slope steepness of $13 \%$ and an elevation ranging from 447 to $506 \mathrm{~m}$ a.s.l. The area has a Mediterranean continental climate, with an average annual rainfall of $406 \mathrm{~mm}_{\text {year }}{ }^{-1}$ (between 2002 and 2016), with two rainy periods, in spring and autumn, and a dry summer with occasional thunderstorms. Rainfall intensity varies during an average year with low values between November and March (ranging from 1.2 and $2.4 \mathrm{~mm} \mathrm{~h}^{-1}$ ), and high values between June and October (from 3.8 and $6.1 \mathrm{~mm} \mathrm{~h}^{-1}$ ). The highest peaks of maximum rainfall intensity 
$\left(I_{30 \max }\right)$ were recorded in September and October with average values of $I_{30 \max }$ between 50 and $53 \mathrm{~mm} \mathrm{~h}^{-1}$. Hence, different hydrological soil responses and runoff depths are expected depending on the month of the year. Saturation-excess runoff areas (generated when the soil becomes saturated) were not observed in the study area, and so infiltration-excess runoff (created when rainfall intensity is greater than the infiltration rate) is the predominant overland flow generation process.

The land is mainly devoted to agriculture (Figure 1). Four vineyards (two in SB-1 and two in SB-2), one cereal field and six small abandoned olive groves are located on the lower portion of the hillslope. The abandoned olive groves are arranged in stepped terraces (without stone walls) and on very low slopes. Four cereal fields (conventional tillage with a roller plough) and one commercial olive grove (314 trees) occupy the higher ground in the sub-catchment. Small and scattered patches of natural vegetation (holm oaks, shrubs and grasses) appear throughout the landscape. One unpaved road ( $4 \mathrm{~m}$ wide) crosses the study area from northwest to southeast, separating the upper and lower portions of the hillslope. There are small, narrow and sparse vegetation strips between the vineyards and the road, in slightly elevated areas the farmers have created with machinery to prevent runoff entering the field and consequently eroding the soil. The vineyard plantation comprises 15,039 grapevines arranged in 147 straight lines (espalier system). Due to the farmer's tillage practices, the soil in the grapevine lines (row hereafter) was 8 to $23 \mathrm{~cm}$ (13 cm on average) higher than in the interrow areas. Soil in the inter-row areas was not ploughed during this study and a very short and sparse vegetation cover protected the soil in spring. The base of the trunks of the olive trees [on the upper slope] were covered with soil following a traditional, regional tillage practice, thus creating a small 'island' of bare soil around each tree. The remaining soil surface between the trees was kept bare by ploughing (reduced tillage; Supplementary Figure 1). The rows in two of the vineyards are arranged somewhat perpendicular to the hillslope flow direction, causing artificial microtopographic flow directions. However, the soil in three vineyards, two cereal fields and the commercial olive grove is affected by ephemeral gullies (EG). This process has triggered the development of continuous flow path lines, breaking the topographic thresholds of the rows in some sections. Soil loss and sediment delivery processes are intense, having led to the formation of three depositional areas (alluvial fans) at the foot of two vineyards and of the commercial olive grove. The largest fan $\left(1480 \mathrm{~m}^{2}\right)$ is near the outlet and lies within the northern vineyard. Soil redistribution interferes with grapevine harvest operations carried out with machinery because the average height of bunches above the soil surface increases in those areas with net soil loss and decreases in the sedimentation prone 
areas. The latter process is particularly evident in the large depositional area. An accurate assessment of runoff and sediment connectivity is required for plantation sustainability and therefore requested by the owner.

\section{DEM acquisition and preprocessing}

The six photogrammetric DEMs were obtained by the company 3Dscanner Patrimonio $e$ Industria (Zaragoza, Spain; http://3dscanner.es/es/). The staff used a digital camera (model DSC-WX220, $4.45 \mathrm{~mm}$ ) with a resolution of $4896 \times 3672$ and a focal distance of $4.45 \mathrm{~mm}$. The camera was fitted to a professional mapping drone (model eBee by senseFly Ltd., CheseauxLausanne, Switzerland) and the flight lasted ca. 30 minutes. In order to minimise the effect of the vegetation on the photogrammetric restitution technique, pictures were taken in early spring, before the cereals had grown and new sprouts and leaves had appeared on the grapevines. Images were corrected by using 8 ground control points with sub-cm accuracy (more details in Supplementary Figure 2). A point cloud was then generated and vegetation points were deleted with the 'standard' algorithm (called 'Point Cloud and Mesh') of the photogrammetric software Pix4Dmapper 3.2. This step increased the density of 3D points of the 3D model computed in the first step that included (i) automatic aerial triangulation, (ii) bundle block adjustment, and (iii) camera self-calibration steps multiple times, till an optimal reconstruction was achieved. Points were removed in the manually drawn areas (polygons) with vegetation cover (forest patches, olive trees and grapevine trunks). The point removal criterion was to remove the minimum number of points necessary. Areas of vegetation are hard to match and so eighth size images (1/8; fault-tolerant scale) were used to calculate more 3D points. The software user's guide recommends a quarter and an eighth of the original size of the images for projects with vegetation to obtain greater point cloud densification (Niederheiser et al., 2016). Gaps were then filled by interpolation, using the contour values for each gap. During the field survey the whole surface of the cereal fields appeared under bare soil conditions, as did most of the vineyard plantation (except the trunks of the grapevines), and so the original terrain points for the cultivated soils (the main focus of this study) required very little correction. The effect of these treatments was negligible in the vineyards, yet it was very clear in the trees (Supplementary Figure 3). As there is not available any other source of topographical data at very high spatial resolution $(<1 \mathrm{~m})$, we could not estimate the actual error of the corrected DEMs in the dense vegetation areas. Finally, each DEM was generated 
independently at high and very high spatial resolution, from 0.03 to $1 \mathrm{~m}$. The technical aspects of the flight and derived products are summarized in Table I.

Index of hydrological connectivity

We used Cavalli et al.'s $(2013,2015)$ modifications to the index of runoff and sediment connectivity (IC), originally proposed by Borselli et al. (2008), regarding the flow accumulation algorithm and maximum slope threshold. We chose this index from the literature due to three reasons: (i) it is a well-known, world-wide used and accepted index by the scientific community; (ii) it can be easily calculated in a GIS environment; and (iii) it can be used for monitoring changes in connectivity in areas with high geomorphological or human induced evolution rates. The model accounts for the drainage area and flow path characteristics. The downslope module $\left(D_{d n}\right)$ contemplates the probability that runoff and sediment arrive at a defined sink along the flow path. The upslope module $\left(D_{u p}\right)$ represents the potential for downward routing of overland flow occurring upslope and also implements a "stream power"like approach, taking into account the slope and size of the contributing area:

$$
I C_{K}=\log _{10}\left(\frac{D_{u p, K}}{D_{d n, K}}\right)=\log _{10}\left(\frac{\overline{W_{K}} \cdot \overline{S_{K}} \cdot \sqrt{A_{K}}}{\sum_{i=K, n_{K}} \frac{d_{i}}{W_{i} \cdot S_{i}}}\right)
$$

where: $A$ is the upslope contributing area $\left(\mathrm{m}^{2}\right), \bar{W}$ is the average weighing factor of $A$ (dimensionless), $\bar{S}$ is the average slope gradient of $A\left(\mathrm{~m} \mathrm{~m}^{-1}\right), d_{i}$ is the length of the $i$ th cell along the downslope path $(\mathrm{m}), W_{i}$ is the weight of the ith cell (dimensionless), and $S_{i}$ is the slope gradient of the $i$ th cell $\left(\mathrm{m} \mathrm{m}^{-1}\right)$. Slope steepness of less than 0.005 must be adjusted to $S_{i}$ $=0.005$ and those higher than 1 must be set to a maximum value of 1 . The subscript $K$ indicates that each cell " $i$ " has its own IC value. This index is defined in the range of $[-\infty,+\infty]$ and connectivity increases when $I C$ grows towards $+\infty$.

The weighted flow path length, the $\bar{W}, \bar{S}$ and $A$ factors were calculated with the D-infinity flow accumulation algorithm (Tarboton, 1997) available in the software $S A G A^{\odot} 2.1 .264$ bit (Conrad et al., 2015), instead of using the D8 single-flow algorithm of the original connectivity model. It is vital that a suitable algorithm is selected to model overland flow processes in hilly landscapes without permanent streams in order to obtain accurate simulations (López-Vicente et al., 2014). The D-infinity approach is recommended by the European SedAlp sediment transport in mountain basins research group (Cavalli et al., 2015) and also used in the TauDEM 
5.2 tools suite for the extraction and analysis of hydrological information from topographical data (Tarboton, 2013). According to these authors, the D-infinity approach captures the actual flow paths, especially on hillslopes where divergent flow predominates. Another reason for choosing the D-infinity approach relates to DEM cell size. If the cell size is smaller than the width of the channels in the study area, then using the single-flow algorithm to derive flow accumulation would limit high drainage areas (i.e., the channel network) to single cell sequences, thus underestimating channel widths. By contrast, the D-infinity algorithm provides a better approximation of channel width by partitioning flow over the entire cross section. The D-infinity algorithm therefore produces a more representative pattern of the $I C$ at sub-basin and hillslope scales (Martínez-Murillo and López-Vicente, 2017). Since there was no permanent stream network, the outlet was chosen as the user-specified target for the $I C$ computation.

\section{Model parameterization}

Before computing the $I C$, the continuity of the flow path lines across the entire hillslope was guaranteed by removing the local depressions in the six DEMs using the Planchon and Darboux algorithm (2001) (available in $S A G A^{\mathbb{O}} 2.1 .264$ bit). This algorithm imposes a gradient to avoid the typically unrepresentative flat surfaces induced by other sink-filling tools. We considered that a minimum gradient of $0.01^{\circ}$ would enable flow routing across the filled sinks. The boundary of the sub-catchment was then automatically calculated upwards from the outlet using $\operatorname{ArCGIS} S^{\odot} 10.3$. This boundary was calculated for each spatial resolution to ensure $I C$ was computed consistently.

In the original version of the $I C$ model, as well as in other studies, the $W$ factor of Eq. (1) is equal to the RUSLE C-factor. We also chose this factor, instead of using other landscape factors such as surface roughness (Cavalli et al., 2013) or drainage density (Gay et al., 2016), so we could use a stable input layer that did not change during the different computations at the six spatial resolutions. Incorporating the RUSLE C-factor therefore reduced uncertainties in the IC model computations. We limited the influence of resolution to the remaining factors: slope (at least partly), upslope area (in $D_{\text {up }}$ ) and flow length (in $D_{d n}$ ). The $W$ factor map was derived from the vector map of land uses, which was manually mapped in great detail using the tools included in the software $Q G I S^{\odot}$ 2.14.0-Essen; 19 different classes were identified (Figure 1e). Within the four vineyards, all row and inter-row areas were mapped, as well as the small areas associated with each grapevine within the rows. RUSLE C-factors were obtained from Novara et al. (2011) and Martínez-Casasnovas et al. (2016) for the vineyards; from Gómez et al. (2003) 
for the olive grove; from Panagos et al. (2015) for the cereal fields and grasslands; from Miller et al. (2003) for the holm oaks; from Schwab et al. (1996) for the trails and road; and from López-Vicente et al. (2013b) for the remaining land uses.

\section{Geomorphic metrics}

At the hillslope scale, the $I C$ inputs were analysed in terms of: i) the upslope contributing area $\left(A, \mathrm{~m}^{2}\right)$; and ii) the slope $(S, \%)$. To analysis different aspects of the effect of the DEM resolution on modelled surface hydrological features, we assessed the following topographic parameters: i) the number of sub-basins; ii) the shape of the sub-catchment boundary; iii) the flow width $(F W, \mathrm{~m})$; iv) the soil roughness $(S R, \mathrm{~mm})$; and $\mathrm{v})$ the convergence index $(\mathrm{Cl}, \%)$. Different algorithms have been proposed in the literature to quantify surface roughness. We calculated $S R$ from the standard deviation of point elevations. This method meets most of the requirements summarized by Hani et al. (2011) for an ideal algorithm designed to carry out a distributed analysis of surface morphology; it is a well-known and accepted measure of roughness (Kamphorst et al., 2000; Tian et al., 2011). The Cl, proposed by Köthe et al. (1996), uses the aspect values of neighbouring cells to parameterise flow convergence and subsequently divergence. It is similar to plan curvature, but does not depend on absolute height differences (Olaya and Conrad, 2009). It calculates the smooth horizontal curvature as a percentage; negative values correspond to convergent and positive to divergent flow conditions. So a value of +100 would represent the peak of a cone, -100 a pit, and 0 a flat surface. The $\mathrm{Cl}$ is useful in lineament analysis, especially those represented by ridges or channel systems, and also as a valley recognition tool (Claps et al., 1994). The $C l$ is dependent on the user-specified search radius, and the $S R$ calculated in this study depends on the cell size and the search radius. Some authors, and using high spatial resolution DEMs, around $1 \times 1 \mathrm{~m}$, suggested detrending the original terrain heights with the roughness measures to generate the residual topography (Berti et al., 2013). In the present study, we kept the original ground heights of the six DEMs to preserve information about the different tillage practices and land use management for three reasons: (i) the centimetre spatial resolution of the features derived from these practices are at the same resolution as the analysed DEMs; (ii) the clear influence of these factors on the $I C$ model; and (iii) the lack of fractures, trenches and isolated blocks that could generate outliers in the slope and surface roughness maps. Armstrong (1986) demonstrated that tillage practices introduce an order of persistence in the soil roughness regardless of the magnitude and/or scale of the study, reducing the fractal dimensions of $S R$ 
from 2 to 1.7. Four geomorphic metrics were estimated with $S A G A^{\odot} 2.1 .264$ bit: $A$ with the 'Catchment Area (Parallel)' tool; FW with the 'Flow Width and Specific Catchment Area' tool, using the multiple flow direction method; $S R$ with the 'Residual Analysis (Grid)' tool, with a radius of 2 cells (including the centre cell); and $C l$ with the 'Convergence Index (Search Radius)' tool, with a radius of 1 cell and using slope as gradient. We used the same moving window (number of cells) to generate the $S R$ and $C l$ maps for each of the six DEM resolutions. Despite the different circle sizes (in terms of the total area) generated at the six DEMs, we chose a fixed window owing to the different tillage practices of the different compartments of the woody crops and the cereal fields. This variability did not allow define an optimal moving window (tillage-scale) for each DEM. The other three metrics were calculated with $Q G I S^{\mathcal{O}}$ 2.14.0-Essen.

As Borselli's index depends on the upslope contributing area, factor $A$ in Eq. (1), the IC maps obtained at the six DEM resolutions were analysed in detail after value normalisation. Fractal geometry is expected due to the decreasing cell size, thus normalisation of the $I C$ distributions improved comparisons between the different HC maps with varying drainage area sizes and microtopographic characteristics (Momm et al., 2013). We used the $\operatorname{ArcGIS}^{\mathcal{O}} 10.3$ rescale tool with a linear transformation function to normalise the $I C$ values from 1 to $10\left(I C_{\text {norm }}\right)$. The mean values of $I C_{\text {norm }}$ were then calculated for the main land uses and geomorphic features using the raster calculator tool. To compare the spatial patterns of $A$ and $F W$ we mapped and measured the rills in the inter-row areas, the ephemeral gullies and the soil-depositional areas. We also characterised the elevated areas of (i) the narrow vegetation strips between the vineyards and the road; and (ii) the grapevine rows.

\section{Results}

Topographic and microtopographic features

Before executing the Planchon and Darboux algorithm (2001) to remove the local depressions, the number of sub-basins identified at the six DEM resolutions markedly increased from the lowest to the highest resolution, as was predicted, because of the high number of small sinks in the high-resolution DEMs. Once the algorithm had been applied, just one sub-basin was apparent at all resolutions. At the same time, the sub-catchment perimeter increased with increasing resolution, it was up to $10 \%$ longer at the highest DEM resolution compared to the lowest resolution model because of the fractal geometry of this feature. The shape of the sub- 
catchment boundary changed for each DEM resolution, exhibiting clear differences in three areas and small differences in four other areas located in the southern part of the subcatchment. We only observed one area with small differences in the northern part (Figure 2). The largest differences ranged between 11 and $24 \mathrm{~m}$. In most sections, the six calculated boundaries matched each other well and differences were less than $1.5 \mathrm{~m}$ that was comparable to the lowest resolution. However, there were no significant differences in the total sub-catchment area. The flow accumulation maps generated at the six spatial resolutions presented clear differences regarding the values for the upslope contributing area and their spatial patterns (Figure 3). A decreased constantly with increasing resolution, with mean values of $359,74,3.5,1.3,0.6$ and $0.3 \mathrm{~m}^{2}$ at cell sizes of $1,0.5,0.2,0.1,0.05$ and $0.03 \mathrm{~m}$ (Figure 4a). The maximum value of $A\left(272,087 \mathrm{~m}^{2}\right)$ was obtained at the lowest DEM resolution, whereas the lowest maximum values $\left(2,924\right.$ and 4,196 $\left.\mathrm{m}^{2}\right)$ were generated at resolutions of 0.1 and $0.03 \mathrm{~m}$, respectively. The lowest coefficient of variation (cv) of $A$ was recorded for the $0.2 \mathrm{~m}$ of cell ( $\mathrm{cv}=9.8)$ and clearly increased $(\mathrm{cv}=18.9$ and $\mathrm{cv}=23.3)$ for smaller cells, 0.05 and $0.03 \mathrm{~m}$, respectively. The flow pathways obtained at cell sizes of 1 and $0.5 \mathrm{~m}$ drew continuous lines, whereas some breakdown points appeared in the flow pathways for 0.2 and $0.1 \mathrm{~m}$ cells, mainly associated with the grapevine lines. There were several broken points throughout the fields, in both the rows and inter-row areas, for the highest resolution DEMs (0.05 and $0.03 \mathrm{~m})$.

As expected flow width $(F W, \mathrm{~m})$, which can be linked to lateral connectivity processes (from the hillslopes to the main channels; Boulton et al., 2017), decreased linearly with increasing resolution, at sub-catchment scale and within all land uses (Figure 4b). FW values in the interrow areas of the vineyards and the commercial olive grove were less than those in the rows and below the trees at all six DEM resolutions. The narrowest paths were calculated within the ephemeral gullies and low values of $F W$ were obtained for the trails and corridors in the vineyards. The largest relative differences, which reached $27 \%$, in $F W$ between the different land uses were recorded at a cell size of $0.2 \mathrm{~m}$. The smallest differences $(6 \%$ and $3 \%)$ were observed for the 0.05 and 0.03 m cells. The average slope, $S$ in Eq. (1), increased progressively with increasing resolution, from 11.5 to $13.6 \%$ at 1 and $0.03 \mathrm{~m}$, respectively.

The two surface microtopography metrics also changed in function of DEM resolution and land use (Figure 5) (Table II). On average, soil roughness (SR, $\mathrm{mm}$ ) for woody crops was $13 \%$ lower in the inter-row areas than below the grapevines and olive trees. This difference was greatest (14.7\%) at resolutions of 0.5 and $0.03 \mathrm{~m}$ and smallest at $1(10.2 \%)$ and $0.2 \mathrm{~m} \mathrm{(12.7 \% ).}$ The mean convergence index $(\mathrm{Cl}, \%)$ in all inter-row areas was negative (concave surface) for all six DEM resolutions and positive (convex surface) in the rows and below the trees. 
Conversely, the largest differences between these two areas were observed at a resolution of $0.2 \mathrm{~m}$ and the smallest differences at 0.05 and $0.03 \mathrm{~m}$. The forestry patches had the highest $S R$ values and small positive values of $\mathrm{Cl}$. The outlet had the lowest $S R$ and $\mathrm{Cl}$ values at all six DEM resolutions. The depositional areas had low $S R$ values and the ephemeral gullies presented low $\mathrm{Cl}$ values.

\section{Index of hydrological connectivity}

Before value normalisation, there were clear disparities between the six IC maps in terms of both their spatial patterns and the range of values (Figure 6). The mean IC values were -5.86, $6.52,-6.95,-6.93,-7.48$ and -7.76 , at DEM resolutions of $1,0.5,0.2,0.1,0.05$ and $0.03 \mathrm{~m}$, respectively. The coefficients of variation were $-0.13,-0.11,-0.10,-0.13,-0.12$ and -0.09 . The IC spatial patterns mirrored the flow paths patterns, showing clear differences in the spatial distribution of the connectivity values within each land use. The patterns of the three vineyard compartments (rows, inter-row areas and corridors) were characterised by straight lines, whereas the patterns in the cereal fields and forestry patches were defined by topography (aspect and slope). The location of the olive trees and the soil covering the base of their trunks was evident as these features acted as divergence points for connectivity lines within the grove. A mixed pattern appeared in the abandoned, terraced olive groves with very low IC values in the almost flat terraced areas. The trails, the corridors through the vineyards and the ephemeral gullies represented features that connected the different landscape compartments to the outlet effectively.

After value normalisation, the highest mean and standard deviation values of $I C_{\text {norm }}$ were obtained with the DEM at $0.2 \mathrm{~m}$, appearing the largest dispersion in the predicted connectivity values at this spatial resolution (Table III). The least variation in $I C_{\text {norm }}$ appeared at resolutions of $1,0.05$ and $0.03 \mathrm{~m}$. Regarding land use, the highest values of $I C_{\text {norm }}$ appeared in the outlet and the ephemeral gullies, demonstrating good agreement with the location of the main erosional geomorphic features (Figure 7). The unpaved trails and the corridors in the vineyards also presented high $I C_{\text {norm }}$ values. The lowest $I C_{\text {norm }}$ values were observed in the grapevine lines and below the olive trees, especially within the abandoned, terraced olive groves. The three depositional areas also had low values of $I C_{n o r m}$, but their average values were higher than in the rows at all DEM resolutions, apart from 1 and $0.03 \mathrm{~m}$. $I C_{\text {norm }}$ remained higher in the interrow areas of all woody crops than the values estimated for the rows and below the trees. This 
trend applied to all six DEM resolutions, although the largest differences (mean 14\% higher) appeared for the model generated with a $0.2 \mathrm{~m}$ cell.

\section{Discussion}

\section{Overland flow and microtopography}

The differences in the shape of the sub-catchment boundary can be explained by the small variations in elevation near the boundary line, both in vegetated areas and cultivated soils under bare soil conditions, but especially in areas with low gradient. Our results agree with those reported by Vaze et al. (2010) for a large forest area in Australia; however, these differences were not expected to have an influence on the $I C$ because computations were carried out after sink filling. The continuous flow pathways and the larger upslope contributing areas observed at low DEM resolutions $(1$ and $0.5 \mathrm{~m}$ ) provided an integrated view of overland flow processes that can be associated with landscape and long-term scales. This type of flow pathways are generated by both high-frequency, low-intensity runoff events and rare, but geomorphologically significant, high-intensity runoff events (Cerdà et al., 2011). The larger upslope contributing areas $(A)$ obtained at these DEM resolutions support this assumption. In an agricultural catchment, Marchamalo et al. (2016) observed that the main pathways remained disconnected during low-intensity rainfall events, but in a higher intensity event, the pathways became fully connected and formed a network. However, the flow pathways at low resolutions produced an unsatisfactory and inaccurate field-scale representation of some features, e.g., the rills in the inter-row areas and surrounding the small and sparse vegetation strips, and also misrepresented the divergent flow path lines in the convex and sedimentationprone areas. The tortuosity of the actual flow route down the slope, observed in the field, was better represented by the DEMs with a resolution of 0.2 and $0.1 \mathrm{~m}$, especially within the interrow and the convex areas surrounding the grapevines. This overland flow pattern explained the higher values of $I C_{\text {norm }}$ obtained for the inter-row areas at 0.2 and $0.1 \mathrm{~m}$ (mean $I C_{\text {norm }}=6.40$ and 6.36, respectively), because the pathways to the target (outlet) were shorter (lower tortuosity). The flow patterns at grid resolutions of similar orders of magnitude as the vertical surface components in the woody crops, i.e., at 0.1 and $0.2 \mathrm{~m}$, can be linked to the most frequent low- and medium-intensity runoff events. The flow paths were apparently highly unconnected at the highest DEM resolutions, 0.05 and $0.03 \mathrm{~m}$, and so we have assumed this result is unrealistic. 
The slight increase in the derived slope $(S)$ with increasing resolution can be explained by the contribution of the highest values of $S$ at high resolutions. At medium and low DEM resolutions, the differences in elevation were buffered by the average topography values, whereas elevation variations at a local scale were more evident at the highest resolutions. Moreover, elevation variations were divided by the distances between cells in order to calculate the slope. As the inter-cell distances were very small in the high-resolution DEMs the slope increased. The differences in flow width $(F W)$ were explained by the cell size of the DEMs. Based on field observations, values of $F W$ calculated at a resolution of 1 and $0.5 \mathrm{~m}$ overestimated the actual size of the rills and ephemeral gullies (López-Vicente and Álvarez, 2017). The average $F W$ in the ephemeral gullies calculated with $0.2 \mathrm{~m}$ cells was similar to the actual width of these features. Modelled FW were too narrow at higher DEM resolutions. In a large agricultural area in Canada, Woodrow et al. (2016) found a significant disagreement (between $29.4 \%$ and $37.3 \%$ of the study area) in mapped contributing areas and flow path lengths at the scale of individual fields in function of DEM resolution, from 1 to $10 \mathrm{~m}$. Our results of modelled FW agree with those reported by Ariza-Villaverde et al. (2015), who found that the suitable flow accumulation threshold value increased as DEM resolution increased, but these authors did not assess DEM down to centimetre resolutions. Although the $I C$ did not account for $F W$, the latter could have an effect on lateral connectivity processes, as observed by López-Vicente et al. (2017b) after analysing the spatial location of the preferential HC routes in a forest plantation affected by tree thinning and skidding trails.

We argued that data acquisition and preprocessing lead to accurate DEMs, especially in vineyards (see Supplementary Figure 3). Hence, the observed differences in $S R$ and the $C I$ between the different compartments of the woody crops represent actual differences and are not artefacts due to data acquisition, preprocessing or DEM generation. These differences were dependent on the different land uses and tillage practices. Maps and values of $S R$ and the $\mathrm{Cl}$ showed good agreement with the main geomorphic features, such as rills, ephemeral gullies and depositional areas at the six DEM resolutions (Figure 7). The evolution of these metrics agreed with the results of Brasington et al. (2012), who found that all geospatial metrics in a long braided river reach experienced a significant loss of topographic complexity with decreasing DEM resolution (from 0.1 to $1 \mathrm{~m}$ ). Our results may be of interest when assessing the delay to the onset of runoff generation in the early stages of a runoff event in vineyard inter-row areas (quick), corridors (average) and rows (slow) because of different $S R$ values. However, this prediction only relates to the microtopographic characteristics and does not take into account the effect of different vegetation covers in each field compartment. This 
proposal agreed with observations by Peñuela et al. (2016) who proposed a link between differences in soil roughness values and overland flow dynamics (diffuse or concentrated) in tilled plots monitored for two years using $0.01 \mathrm{~m}$ resolution DEMs.

\section{Structural and functional connectivity and optimum DEM resolutions}

The evolution of the $I C$ at a sub-catchment scale and before value normalisation disagreed with that reported by Cantreul et al. (2016) after using the original Borselli's index to compare eight different DEM resolutions $(12,24,48,72,96,204,504$ and $996 \mathrm{~cm}$ ) in a 124 ha catchment. These authors found the $I C$ increased for a given pixel when the pixel size decreased. After value normalisation, our results agreed with those of Cantreul et al. for DEM resolutions from 1 to $0.2 \mathrm{~m}$, and disagreed over a range of 0.2 to $0.05 \mathrm{~m}$. However, the $I C$ values at the outlet concurred with other hydrological connectivity and soil erosion modelling studies: (i) Habtezion et al. (2016) examined the effects of nine DEM resolutions on watershed hydrologic modelling, from 0.02 to $0.8 \mathrm{~m}$, in a small experimental field plot and observed that lower DEM resolutions tended to eliminate topographic features and thus surface depression storage was less represented; this leads to an overestimation of hydrological connectivity; and (ii) Deumlich et al. (2017), using the EROSION-3D model in two cultivated plots, predicted decreasing median values of soil erosion with increasing resolution $(25,10,5,2$ and $1 \mathrm{~m})$. The actual width of some microtopographic connections (rills and ephemeral gullies), which is similar to cell size (from rills a few centimetres wide to ephemeral gullies with a width of 20 to $30 \mathrm{~cm}$ ), may explain our results and how they compare to other studies. As Cavalli et al. (2013) highlighted, the values and spatial patterns of the $I C$ are highly dependent on the target and evidently different when connectivity is analysed in terms of the main channels instead of the catchment outlet. Thus, the results of our study correspond to a static and average scenario for the study area, with the outlet as target.

Structural connectivity is defined as the connectivity of surface conditions that are susceptible to overland flow generation and transport, it is a principal component used to describe the hydrologic response on fragmented landscapes (Williams et al., 2016). The values of $I C_{\text {norm }}$ obtained for the inter-row areas of all woody crops were higher than the values estimated for the rows and below the trees, which agreed with the results presented by Marchamalo et al. (2016) who showed that manmade lines such as terrace embankments and tracks have a major and positive influence on sediment connectivity. After analysing the variability in the topographic and microtopographic metrics and in the $I C_{\text {norm }}$, we found that 
the highest relative differences in all metrics occurred at a resolution of $0.2 \mathrm{~m}$ (Figure 7). At the same time, this spatial resolution was comparable with and slightly higher than the vertical ground components in the woody crops, which were divided into row and inter-row areas with different tillage practices. This outcome is similar to the threshold DEM resolution for field plots of $0.1 \mathrm{~m}$ proposed by Habtezion et al. (2016) which is based on ponded area simulations and fractal analysis. Additionally, computational demand at $0.2 \mathrm{~m}$ was much lower than the time-consuming modelling at a DEM resolution of 0.05 and $0.03 \mathrm{~m}$. Hence, a cell size of $0.2 \mathrm{~m}$ appears to be the recommended DEM resolution for studying and modelling structural $\mathrm{HC}$ in woody crops. The optimal DEM resolution for hydrological modelling studies in other areas and crops may differ and will depend on soil roughness and tillage practices.

The good agreement observed between the location of the ephemeral gullies and the size of the depositional areas, plus the spatial patterns of the $I C$ predicted at a resolution of $1 \mathrm{~m}$, collectively suggest that DEM resolution controls the degree to which IC values can reflect the functional connectivity (with respect to runoff and erosion processes). Only small parts of the hillslopes are active during short, low-intensity rainfall events and disconnected areas appear, whereas during high-intensity events, runoff is generated throughout the catchment and all parts and compartments of the hillslopes are interconnected. Although the $I C$ is an index of structural connectivity, we suggest that its capacity to identify spatial patterns of functional connectivity during high-intensity rainfall events is greater at lower DEM resolutions. Thomas et al. (2017) also identified optimal DEM resolutions at 1 and $2 \mathrm{~m}$ for large-scale modelling of hydrologically sensitive areas in topographically complex landscapes.

\section{Future research}

The variations in the $I C$ values and spatial patterns derived from the different resolution DEMs allowed us to identify different 'breakthrough' and 'delivery' points along the flow pathways. These results are of interest whenever runoff and mobilised sediments (nutrients and pollutants) could potentially be transported between fields or delivered to the drainage channel network (Thomas et al., 2017). Monitoring runoff yield in the different compartments of the study area will help refine the $I C$ to make associations between this static index and functional connectivity under a range of rainfall and runoff conditions. $I C$ assessment in terms of a different target, such as ephemeral gullies, will contribute to a better understanding of soil redistribution and delivery processes occurring within vineyards at a sub-catchment scale. An evaluation of the minimum runoff depth which ensures the continuity of overland flow at 
local, field and hillslope scales will be of interest when it comes to validating further predictions produced by Borselli's index of hydrological connectivity. Soil roughness measures obtained with different techniques, such as the standard deviation of slope or residual topography, can add complementary information about microtopography and the influence of tillage practices on this parameter. Moreover, the combined use of the C-RUSLE and soil roughness factors as an aggregated metric of the land properties could be used to refine flow path modelling and $I C$ computations.

\section{Conclusions}

The likelihood of horizontal and/or vertical overland flow movement, and therefore hydrological connectivity, can be partially characterized by DEM spatial resolution. The combined analysis of the variability in the topographic and microtopographic metrics, the $I C$ maps and $I C_{\text {norm }}$ values have allowed us to identify the topographic threshold value that controls the structural connectivity in agricultural systems with woody crops. We demonstrated the existence of a threshold DEM resolution at $0.2 \mathrm{~m}$ which improved the model's predictions of $\mathrm{HC}$ in the different compartments of the woody crops. Lower and higher DEM resolutions introduced bias in the input data and hydrological connectivity computations. Accurate assessment of the structural connectivity therefore depends on DEM resolution. Differences in soil roughness (micro and macro) and other management factors, such as wheel spacing and tillage operations, may modify the optimum DEM resolution for other locations and crops. On the other hand, the differences in soil roughness and convergence index between the different woody crop compartments depended directly on tillage practices; this trend was observed at all DEM resolutions. The various microtopographic characteristics revealed a different delay in runoff generation at the early stage of a runoff event in vineyard inter-row areas (quick), corridors (average) and rows (slow).

We observed good agreement between the outputs at the lowest resolution ( $1 \mathrm{~m})$ and the long-term soil redistribution patterns when high-intensity rainfall and runoff events activate the whole sub-catchment. This explains the location and size of the main geomorphic features, such as the ephemeral gullies and the depositional areas. Thus, the capacity of Borselli's index to identify spatial patterns of functional connectivity during high-intensity rainfall events was greater at lower DEM resolutions. The results of this study may help refine the characterization 
of critical source areas in hydrological, soil erosion, and nutrient and pollutant delivery studies, especially in agricultural systems with woody crops.

Acknowledgements - This research was funded by the project "Environmental and economic impact of soil loss (soil erosion footprint) in agro-ecosystems of the Ebro river basin: numerical modelling and scenario analysis (EroCostModel) (CGL2014-54877-JIN)" of the Spanish Ministry of Economy and Competitiveness. We especially thank Mr. Gonzalo Alcalde Fábregas (Fábregas Cellar, D.O. Somontano) for giving up the vineyards where part of this research has been done. Author contributions: M.L.V. conceived and designed the research and wrote the article; M.L.V. and S.A. generated the inputs, performed the research and analysed the data. Finally, the authors wish to acknowledge the Managing Editor (Prof. Stuart N. Lane), the Assistant Editor (Dr. Fiona Kirkby), the Associate Editor and three anonymous reviewers for their detailed and helpful comments to the manuscript.

\section{References}

Ali AMd, Solomatine DP, Di Baldassarre G. 2015. Assessing the impact of different sources of topographic data on 1D hydraulic modelling of floods. Hydrology and Earth System Sciences 19: 631-643.

Antoine M, Javaux M, Bielders C. 2009. What indicators can capture runoff-relevant connectivity properties of the microtopography at the plot scale? Advances in Water Resources 32: 1297-1310.

Ariza-Villaverde $A B$, Jiménez-Hornero FJ, Gutiérrez de Ravé E. 2015. Influence of DEM resolution on drainage network extraction: A multifractal analysis. Geomorphology 241: 243-254.

Armstrong AC. 1986. On the fractal dimensions of some transient soil properties. European Journal of Soil Science (former Journal of Soil Science) 37: 641-652.

Aucelli PPC, Conforti M, Della Seta M, Del Monte M, D'uva L, Rosskopf CM, Vergari F. 2016. Multi-temporal digital photogrammetric analysis for quantitative assessment of soil erosion rates in the Landola catchment of the upper Orcia valley (Tuscany, Italy). Land Degradation \& Development 27(4): 1075-1092.

Berti M, Corsini A, Daehne A. 2013. Comparative analysis of surface roughness algorithms for the identification of active landslides. Geomorphology 182: 1-18.

Boulton AJ, Rolls RJ, Jaeger KL, Datry T. 2017. Hydrological Connectivity in Intermittent Rivers and Ephemeral Streams. In Intermittent Rivers and Ephemeral Streams: Ecology and Management, Datry T, Bonada N, Boulton A (eds.). Academic Press - Elsevier: London, United Kingdom; 89-92.

Borselli L, Cassi P, Torri D. 2008. Prolegomena to sediment and flow connectivity in the landscape: A GIS and field numerical assessment. Catena 75(3): 268-277.

Brasington J, Vericat D, Rychkov I. 2012. Modeling river bed morphology, roughness, and surface sedimentology using high resolution terrestrial laser scanning. Water Resources Research 48: W11519.

Callow JN, Smettem KRJ. 2009. The effect of farm dams and constructed banks on hydrologic connectivity and runoff estimation in agricultural landscapes. Environmental Modelling and Software 24(8): 959-968. 
Cantreul V, Cavalli M, Degré A. 2016. Effect of DEM resolution and comparison between different weighting factors for hydrologic connectivity index. Geophysical Research Abstracts 18: EGU2016-2697-1.

Cavalli M, Crema S, Marchi L. 2015. Guidelines on the Sediment Connectivity stand-alone application SedInConnect. Release: 2.0 and 2.1 [online] Available from: https://github.com/HydrogeomorphologyTools.

Cavalli M, Trevisani S, Comiti F, Marchi L. 2013. Geomorphometric assessment of spatial sediment connectivity in small Alpine catchments. Geomorphology 188: 31-41.

Cerdà A, Brazier R, Nearing M, de Vente J. 2013. Scales and erosion. Catena 102: 1-2.

Chartin C, Evrard O, Laceby JP, Onda Y, Ottlé C, Lefèvre I, Cerdan O. 2017. The impact of typhoons on sediment connectivity: lessons learnt from contaminated coastal catchments of the Fukushima Prefecture (Japan). Earth Surface Processes and Landforms 42: 306-317.

Claps P, Fiorentino M, Oliveto G. 1994. Informational entropy of fractal river networks. Journal of Hydrology 187(12): 145-156.

Conrad O, Bechtel B, Bock M, Dietrich H, Fischer E, Gerlitz L, Wehberg J, Wichmann V, Böhner J. 2015. System for Automated Geoscientific Analyses (SAGA) v. 2.1.4. Geoscientific Model Development 8: 1991-2007.

David CH, Yang Z-L, Hong S. 2013. Regional-scale river flow modeling using off-the-shelf runoff products, thousands of mapped rivers and hundreds of stream flow gauges. Environmental Modelling and Software 42: 116-132.

Deumlich D, Jha A, Kirchner G. 2017. Comparing measurements, ${ }^{7}$ Be radiotracer technique and process based erosion model for estimating short-term soil loss from cultivated land in Northern Germany. Soil and Water Research 12(3): 177-186. DOI:10.17221/124/2016-SWR.

D'Haen K, Dusar B, Verstraeten G, Degryse P, De Brue H. 2013. A sediment fingerprinting approach to understand the geomorphic coupling in an eastern Mediterranean mountainous river catchment. Geomorphology 197: 6475.

Díaz-Vilariño L, González-Jorge H, Martínez-Sánchez J, Bueno M, Arias P. 2016. Determining the limits of unmanned aerial photogrammetry for the evaluation of road runoff. Measurement 85: 132-141.

FAO. 1998. http://faostat.fao.org/site/377/default.aspx\#ancor.

Foerster S, Wilczok C, Brosinsky A, Segl K. 2014. Assessment of sediment connectivity from vegetation cover and topography using remotely sensed data in a dryland catchment in the Spanish Pyrenees. Journal of Soils and Sediments 14: 1982-2000.

Gay A, Cerdan O, Mardhel V, Desmet M. 2016. Application of an index of sediment connectivity in a lowland area. Journal of Soils and Sediments 16(1): 280-293.

Ghumman AR, Al-Salamah IS, AlSaleem SS, Haider H. 2017. Evaluating the impact of lower resolutions of digital elevation model on rainfall-runoff modeling for ungauged catchments. Environmental Monitoring and Assessment 189(2): Article number 54.

Gómez JA, Battany M, Renschler CS, Fereres E. 2003. Evaluating the impact of soil management on soil loss in olive orchards. Soil Use and Management 19(2): 127-134.

Habtezion N, Tahmasebi Nasab M, Chu X. 2016. How does DEM resolution affect microtopographic characteristics, hydrologic connectivity, and modelling of hydrologic processes? Hydrological Processes 30(25): 4870-4892.

Hani AFM, Sathyamoorthy D, Asirvadam VS. 2011. A method for computation of surface roughness of digital elevation model terrains via multiscale analysis. Computers \& Geosciences 37: 177-192.

Heckmann T, Schwanghart W. 2013. Geomorphic coupling and sediment connectivity in an alpine catchment Exploring sediment cascades using graph theory. Geomorphology 182: 89-103. 
Infante-Amate J. 2012. The ecology and history of the Mediterranean olive grove: The Spanish great expansion, 1750-2000. Rural History 23(2): 161-184.

Kamphorst EC, Jetten V, Guérif J, Pitkänen J, Iversen BV, Douglas JT, Paz A. 2000. Predicting depressional storage from soil surface roughness. Soil Science Society of America Journal 64(5): 1749-1758.

Köthe R, Gehrt E, Böhner J. 1996. Automatische Reliefanalyse für geowissenschaftliche Anwendun-gen - derzeitiger Stand und Weiterentwicklungen des Programms SARA. Arbeitshefte Geologie 1: 31-37.

Lane SN, Reaney SM, Heathwaite AL. 2009. Representation of landscape hydrological connectivity using a topographically driven surface flow index. Water Resources Research 45(8): W08423.

López-Vicente M, Álvarez S. 2017. Soil redistribution and nutrient delivery in a Mediterranean rain-fed agroecosystem with different crops and management: environmental and economic aspects. Geophysical Research Abstracts 19: EGU2017-5148.

López-Vicente M, García-Ruiz R, Guzmán G, Vicente-Vicente JL, Van Wesemael B, Gómez JA. 2016a. Temporal stability and patterns of runoff and runon with different cover crops in an olive orchard (SW Andalusia, Spain). Catena 147: 125-137.

López-Vicente M, Nadal-Romero E, Cammeraat ELH. 2017a. Hydrological connectivity does change over 70 years of abandonment and afforestation in the Spanish Pyrenees. Land Degradation \& Development 28(4): 1298-1310.

López-Vicente M, Navas A. 2015. Modelling runoff depth and connectivity in commercial vineyards (DO Somontano, Huesca, NE Spain). Geophysical Research Abstracts 17: EGU2015-7044.

López-Vicente M, Navas A, Gaspar L, Machín J. 2013b. Advanced modelling of runoff and soil redistribution for agricultural systems: the SERT model. Agricultural Water Management 125: 1-12.

López-Vicente M, Pérez-Bielsa C, López-Montero T, Lambán LJ, Navas A. 2014. Runoff simulation with eight different flow accumulation algorithms: Recommendations using a spatially distributed and open-source model. Environmental Modelling \& Software 62: 11-21.

López-Vicente M, Poesen J, Navas A, Gaspar L. 2013a. Predicting runoff and sediment connectivity and soil erosion by water for different land use scenarios in the Spanish Pre-Pyrenees. Catena 102: 62-73.

Marchamalo M, Hooke JM, Sandercock PJ. 2016. Flow and sediment connectivity in semi-arid landscapes in SE Spain: patterns and controls. Land Degradation \& Development 27(4): 1032-1044.

Martínez-Casasnovas JA, Ramos MC, Benites G. 2016. Soil and Water Assessment Tool soil loss simulation at the sub-basin scale in the Alt Penedès-Anoia vineyard region (NE Spain) in the 2000s. Land Degradation \& Development 27(2): 160-170.

Martínez-Murillo JF, López-Vicente M. 2017. Effect of salvage logging and check-dams on simulated hydrological connectivity in a burned area. Land Degradation \& Development. DOI: 10.1002/Idr.2735.

Miller JD, Nyhan JW, Yool SR. 2003. Modeling potential erosion due to the Cerro Grande Fire with a GIS-based implementation of the Revised Universal Soil Loss Equation. International Journal of Wildland Fire 12: 85-100.

Momm HG, Bingner RL, Wells RR, Rigby JR, Dabney SM. 2013. Effect of topographic characteristics on compound topographic index for identification of gully channel initiation locations. Transactions of the ASABE 56(2): 523537.

Niederheiser R, Mokros M, Lange J, Petschko H, Prasicek G, Elberink SO. 2016. Deriving 3D point clouds from terrestrial photographs comparison of different sensors and software. The International Archives of the Photogrammetry, Remote Sensing and Spatial Information Sciences 41: 685-692. DOI: 10.5194/isprsarchivesXLI-B5-685-2016. 
Novara A, Gristina L, Saladino SS, Santoro A, Cerdà A. 2011. Soil erosion assessment on tillage and alternative soil managements in a Sicilian vineyard. Soil \& Tillage Research 117: 140-147.

Olaya V, Conrad O. 2009. Geomorphometry in SAGA. In Geomorphometry, Volume 33, $1^{\text {st }}$ Edition: Concepts, Software, Applications, Hengl T, Reuter H (eds.). Elsevier: Amsterdam, The Netherlands; 291-308.

Page T, Heathwaite AL, Thompson LJ, Pope L, Willows R. 2012. Eliciting fuzzy distributions from experts for ranking conceptual risk model components. Environmental Modelling and Software 36: 19-34.

Panagos P, Borrelli P, Meusburger K, Alewell C, Lugato E, Montanarella L. 2015. Estimating the soil erosion covermanagement factor at the European scale. Land Use Policy 48: 38-50.

Parsons AJ, Bracken L, Poeppl RE, Wainwright J, Keesstra SD. 2015. Introduction to special issue on connectivity in water and sediment dynamics. Earth Surface Processes and Landforms 40(9): 1275-1277.

Peñuela A, Darboux F, Javaux M, Bielders CL. 2016. Evolution of overland flow connectivity in bare agricultural plots. Earth Surface Processes and Landforms 41(11): 1595-1613.

Planchon O, Darboux F. 2001. A fast, simple and versatile algorithm to fill the depressions of digital elevation models. Catena 46(2-3): 159-176.

Prosdocimi M, Burguet M, Di Prima S, Sofia G, Terol E, Rodrigo-Comino J, Cerdà A, Tarolli P. 2017. Rainfall simulation and Structure-from-Motion photogrammetry for the analysis of soil water erosion in Mediterranean vineyards. Science of the Total Environment 574: 204-215.

Reaney SM, Bracken LJ, Kirkby MJ. 2014. The importance of surface controls on overland flow connectivity in semiarid environments: Results from a numerical experimental approach. Hydrological Processes 28(4): 2116-2128.

Sampson CC, Fewtrell TJ, Duncan A, Shaad K, Horritt MS, Bates PD. 2012. Use of terrestrial laser scanning data to drive decimetric resolution urban inundation models. Advances in Water Resources 41: 1-17.

Schwab GO, Fangmeier DD, Elliot WJ. 1996. Soil and water management systems, fourth edition. New York: John Wiley and Sons. $371 \mathrm{pp}$.

Shore M, Murphy PNC, Jordan P, Mellander P-E, Kelly-Quinn M, Cushen M, Mechan S, Shine O, Melland AR. 2013. Evaluation of a surface hydrological connectivity index in agricultural catchments. Environmental Modelling and Software 47: 7-15.

Sougnez N, van Wesemael B, Vanacker V. 2011. Low erosion rates measured for steep, sparsely vegetated catchments in southeast Spain. Catena 84(1-2): 1-11.

Tarboton DG. 1997. A new method for the determination of flow directions and upslope areas in grid digital elevation models. Water Resources Research 33: 309-319.

Tarboton DG. 2013. TauDEM 5.1, Terrain Analysis Using Digital Elevation Models [online] Available from: http://hydrology.usu.edu/taudem/taudem5/

Thomas IA, Jordan P, Shine O, Fenton O, Mellander P-E, Dunlop P, Murphy PNC. 2017. Defining optimal DEM resolutions and point densities for modelling hydrologically sensitive areas in agricultural catchments dominated by microtopography. International Journal of Applied Earth Observation and Geoinformation 54: 3852.

Tian B, Wang L, Koike K. 2011. Spatial statistics of surface roughness change derived from multi-scale digital elevation models. Procedia Environmental Sciences 7: 252-257.

Vaze J, Teng J, Spencer G. 2010. Impact of DEM accuracy and resolution on topographic indices. Environmental Modelling \& Software 25(10): 1086-1098. 
Vigiak O, Borselli L, Newham LTH, McInnes J, Roberts AM. 2012. Comparison of conceptual landscape metrics to define hillslope-scale sediment delivery ratio. Geomorphology 138: 74-88.

Williams CJ, Pierson FB, Robichaud PR, Al-Hamdan OZ, Boll J, Strand EK. 2016. Structural and functional connectivity as a driver of hillslope erosion following disturbance. International Journal of Wildland Fire 25(3): 306-321.

Woodrow K, Lindsay JB, Berg AA. 2016. Evaluating DEM conditioning techniques, elevation source data, and grid resolution for field-scale hydrological parameter extraction. Journal of Hydrology 540: 1022-1029.

Yang J, Chu X. 2013. Effects of DEM resolution on surface depression properties and hydrologic connectivity. Journal of Hydrologic Engineering 18(9): 1157-1169. 


\section{Highlights:}

Modelling predictions of hydrological connectivity depend on the DEM resolution

There is a threshold resolution $(0.2 \mathrm{~m})$ for structural connectivity in woody crops

Optimal surface microtopography characterization appears at $0.2 \mathrm{~m}$ resolution

Rows and inter-row areas have different connectivity patterns and values

Observed functional connectivity was better modelled at low DEM resolutions

GRAPHICAL ABSTRACT:

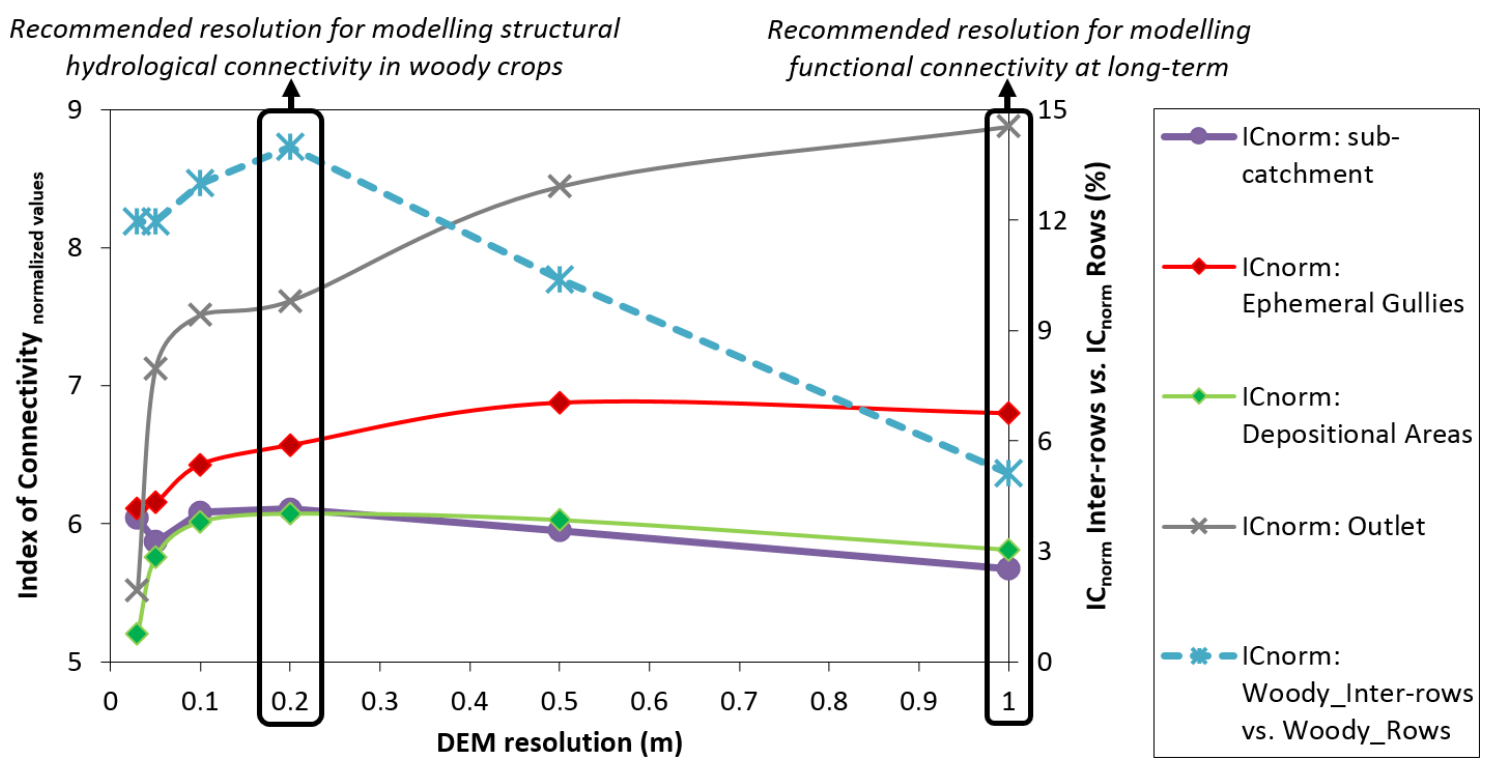

Twitter publicising:

For the first time we demonstrated the existence of a threshold DEM resolution at $0.2 \mathrm{~m}$ to improve model predictions of hydrological connectivity in woody crops 
Table I. Main parameters of the drone flight, pictures and photogrammetry-derived DEMs.

\begin{tabular}{|c|c|c|c|c|c|c|c|}
\hline Date & $\begin{array}{l}\text { Mean } \\
\text { altitude } \\
\text { (m above } \\
\text { ground) }\end{array}$ & $\begin{array}{l}\text { Pictures } \\
\text { (n) }\end{array}$ & $\begin{array}{l}\text { Terrestrial } \\
\text { control } \\
\text { points }(n)\end{array}$ & $\begin{array}{c}\text { Spatial } \\
\text { resolution } \\
(\mathrm{cm} / \text { pixel) }\end{array}$ & $\begin{array}{l}\text { Error of re- } \\
\text { projection } \\
\text { (pixel) }\end{array}$ & $\begin{array}{l}\text { Joint } \\
\text { points } \\
\text { (n) }\end{array}$ & $\begin{array}{c}\text { Surface } \\
\text { covered } \\
\text { (ha) }\end{array}$ \\
\hline 6-Apr-2016 & 130 & 333 & 8 & 3.30 & 1.150 & 45,391 & 66.8 \\
\hline
\end{tabular}

Table II. Mean values of soil roughness $(S R, \mathrm{~mm})$ and the convergence index $(\mathrm{Cl}, \%)$ at sub-catchment scale (BA) and in the main land uses. I-R: inter-row; Co: corridor; CF: cereal fields; AOGT: abandoned olive grove in terraces; UV: understory vegetation (dense and disperse); F\&S: forest and scrubland.

\begin{tabular}{|c|c|c|c|c|c|c|c|c|c|c|c|c|}
\hline \multirow[t]{2}{*}{ Factor } & \multirow{2}{*}{$\begin{array}{l}\text { Resol. } \\
(\mathrm{m})\end{array}$} & \multirow[t]{2}{*}{ BA } & \multicolumn{3}{|c|}{ Vineyard } & \multirow[t]{2}{*}{$\mathrm{CF}$} & \multicolumn{2}{|c|}{ Olive } & \multicolumn{2}{|c|}{ AOGT } & \multirow[t]{2}{*}{$F \& S$} & \multirow[t]{2}{*}{ Trail } \\
\hline & & & Row & I-R & Co & & Tree & Soil & Tree & UV & & \\
\hline \multirow{6}{*}{$\begin{array}{l}S R \\
(\mathrm{~mm})\end{array}$} & 1 & 72.7 & 56.2 & 51.2 & 65.6 & 67.5 & 77.5 & 71.8 & 66.8 & 57.1 & 157.9 & 68.5 \\
\hline & 0.5 & 37.5 & 34.8 & 28.3 & 33.9 & 34.7 & 41.6 & 35.6 & 35.1 & 31.2 & 81.8 & 33.9 \\
\hline & 0.2 & 14.1 & 14.8 & 12.4 & 14.0 & 13.0 & 16.8 & 14.5 & 14.5 & 13.3 & 32.4 & 12.4 \\
\hline & 0.1 & 5.6 & 7.7 & 6.2 & 6.9 & 5.1 & 8.4 & 7.3 & 7.2 & 6.7 & 15.0 & 5.4 \\
\hline & 0.05 & 1.2 & 4.0 & 3.1 & 3.4 & 0.8 & 4.1 & 3.6 & 3.5 & 3.3 & 5.9 & 1.8 \\
\hline & 0.03 & 0.4 & 2.3 & 1.8 & 2.0 & 0.2 & 2.4 & 2.1 & 2.1 & 1.9 & 2.5 & 0.7 \\
\hline \multirow{6}{*}{$\begin{array}{l}\mathrm{Cl} \\
(\%)\end{array}$} & 1 & -0.90 & 7.33 & -0.68 & -1.07 & -0.61 & 12.78 & -2.01 & 5.70 & -5.98 & 3.03 & -9.06 \\
\hline & 0.5 & -1.33 & 13.44 & -4.29 & -1.06 & -0.82 & 8.13 & -2.58 & 3.90 & -5.99 & 1.41 & -6.06 \\
\hline & 0.2 & -1.42 & 23.82 & -5.24 & -0.66 & -0.91 & 3.22 & -1.40 & 1.56 & -3.99 & 0.39 & -3.20 \\
\hline & 0.1 & -1.07 & 13.21 & -2.99 & -0.33 & -0.64 & 1.56 & -0.79 & 0.75 & -2.42 & 0.15 & -1.77 \\
\hline & 0.05 & -0.79 & 6.82 & -1.60 & -0.18 & -0.38 & 0.71 & -0.43 & 0.37 & -1.37 & 0.05 & -0.96 \\
\hline & 0.03 & -0.65 & 4.23 & -0.98 & -0.10 & -0.25 & 0.44 & -0.27 & 0.23 & -0.88 & 0.03 & -0.59 \\
\hline
\end{tabular}

Table III. Values of the normalized IC $\left(I C_{\text {norm }}\right)$ in the whole study area (BA) and in the main land uses. I-R: inter-row; Co: corridor; CF: cereal fields; AOGT: abandoned olive grove in terraces; UV: understory vegetation (dense and disperse); F\&S: forest and scrubland.

\begin{tabular}{|c|c|c|c|c|c|c|c|c|c|c|c|}
\hline \multirow{2}{*}{$\begin{array}{l}\text { Resolution } \\
(\mathrm{m})\end{array}$} & \multirow[t]{2}{*}{ BA } & \multicolumn{3}{|c|}{ Vineyard } & \multirow[t]{2}{*}{$\mathrm{CF}$} & \multicolumn{2}{|c|}{ Olive } & \multicolumn{2}{|c|}{ AOGT } & \multirow[t]{2}{*}{$F \& S$} & \multirow[t]{2}{*}{ Trail } \\
\hline & & Row & I-R & Co & & Tree & Soil & Tree & UV & & \\
\hline 1 & 5.68 & 6.15 & 6.22 & 5.82 & 5.79 & 5.05 & 5.27 & 4.49 & 5.01 & 5.15 & 5.88 \\
\hline 0.5 & 5.95 & 5.90 & 6.23 & 6.21 & 6.15 & 5.36 & 5.82 & 4.48 & 5.32 & 5.53 & 6.34 \\
\hline 0.2 & 6.11 & 5.65 & 6.40 & 6.48 & 6.28 & 5.47 & 5.95 & 4.53 & 5.49 & 5.80 & 6.56 \\
\hline 0.1 & 6.08 & 5.65 & 6.36 & 6.46 & 6.25 & 5.49 & 5.93 & 4.57 & 5.47 & 5.83 & 6.55 \\
\hline 0.05 & 5.86 & 5.49 & 6.13 & 6.23 & 6.01 & 5.33 & 5.71 & 4.46 & 5.27 & 5.65 & 6.31 \\
\hline 0.03 & 6.04 & 5.35 & 6.02 & 6.38 & 6.27 & 5.85 & 6.26 & 4.64 & 5.46 & 5.73 & 6.43 \\
\hline
\end{tabular}




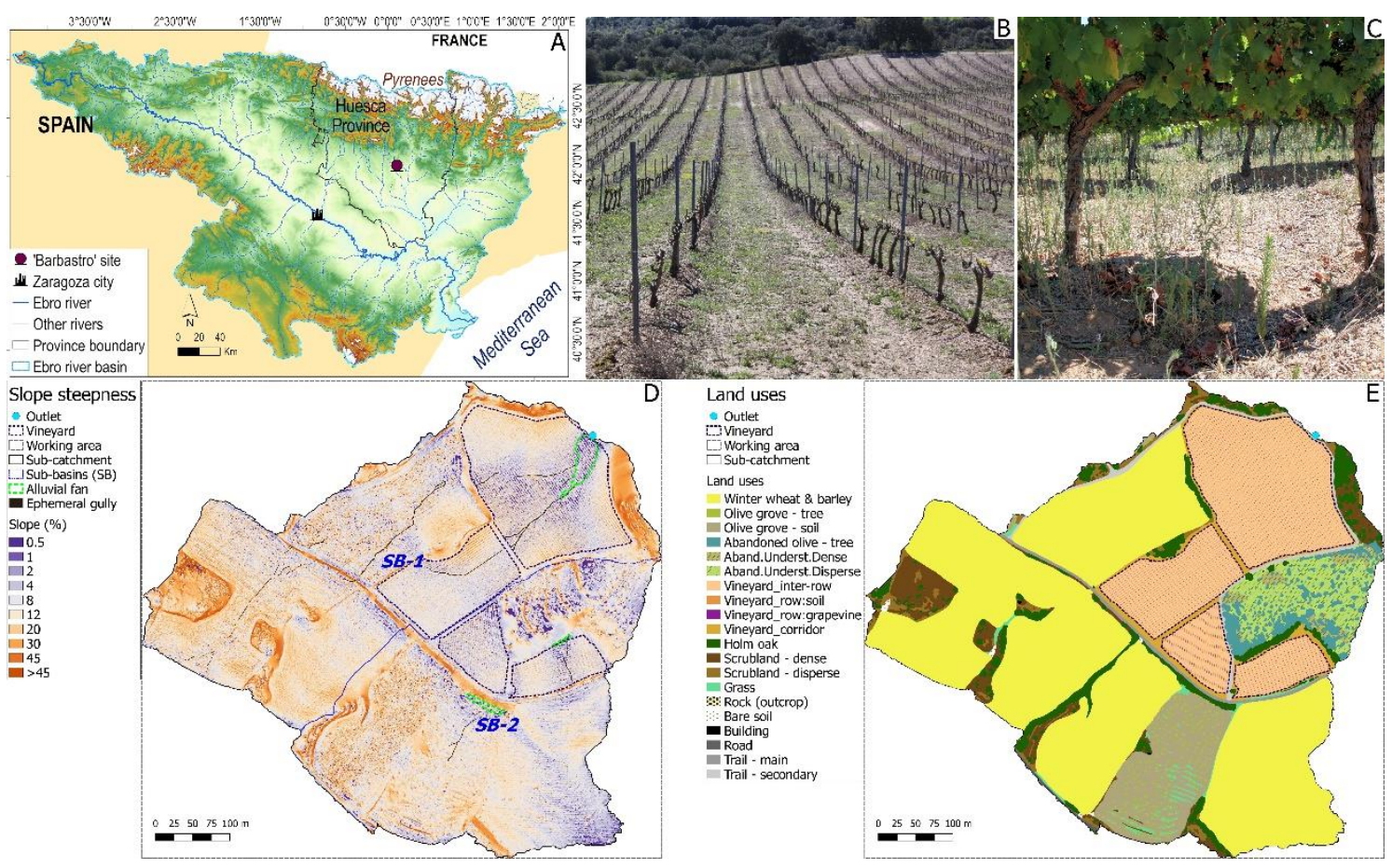

Figure 1. (a) Location of the study area in the Ebro river basin, NE Spain. (b) Images of soil delivery and redistribution processes (April 2016) and (c) one ephemeral gully (July 2016) in the largest vineyard. Maps of (d) slope and (e) land uses.

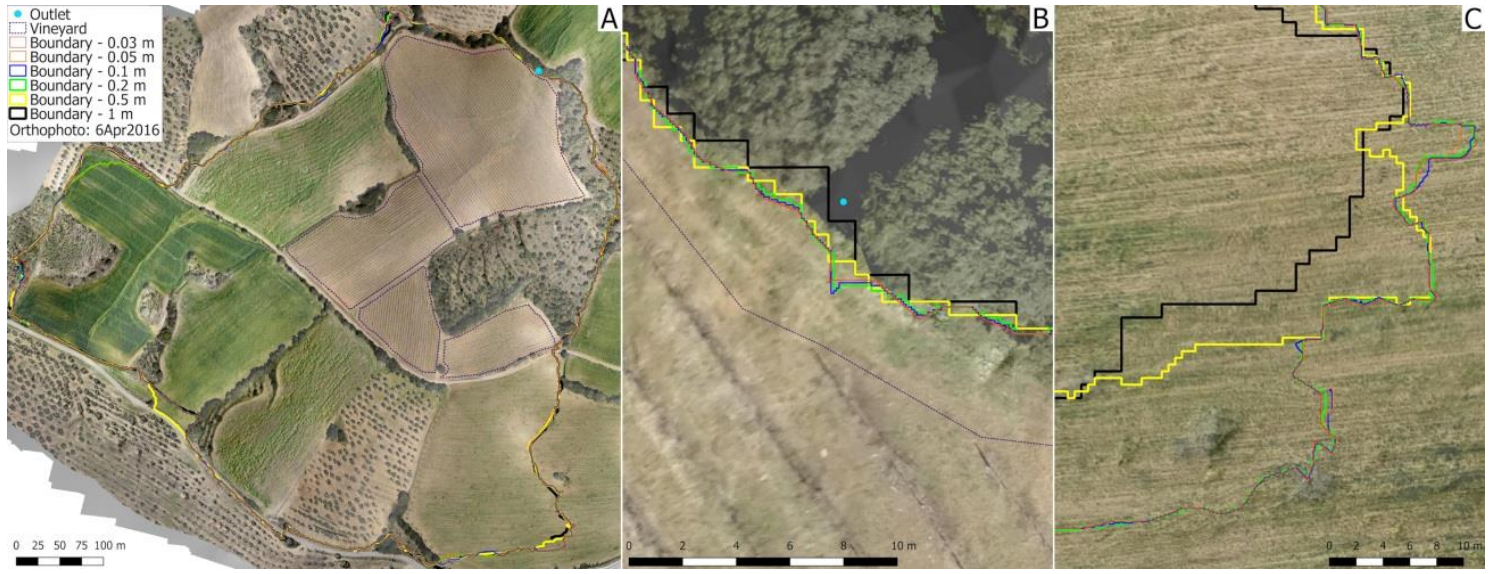

Figure 2. (a) Sub-catchment boundary generated at the six DEM resolutions at a sub-catchment scale and (b) in detail near the outlet and (c) in the cereal field. 


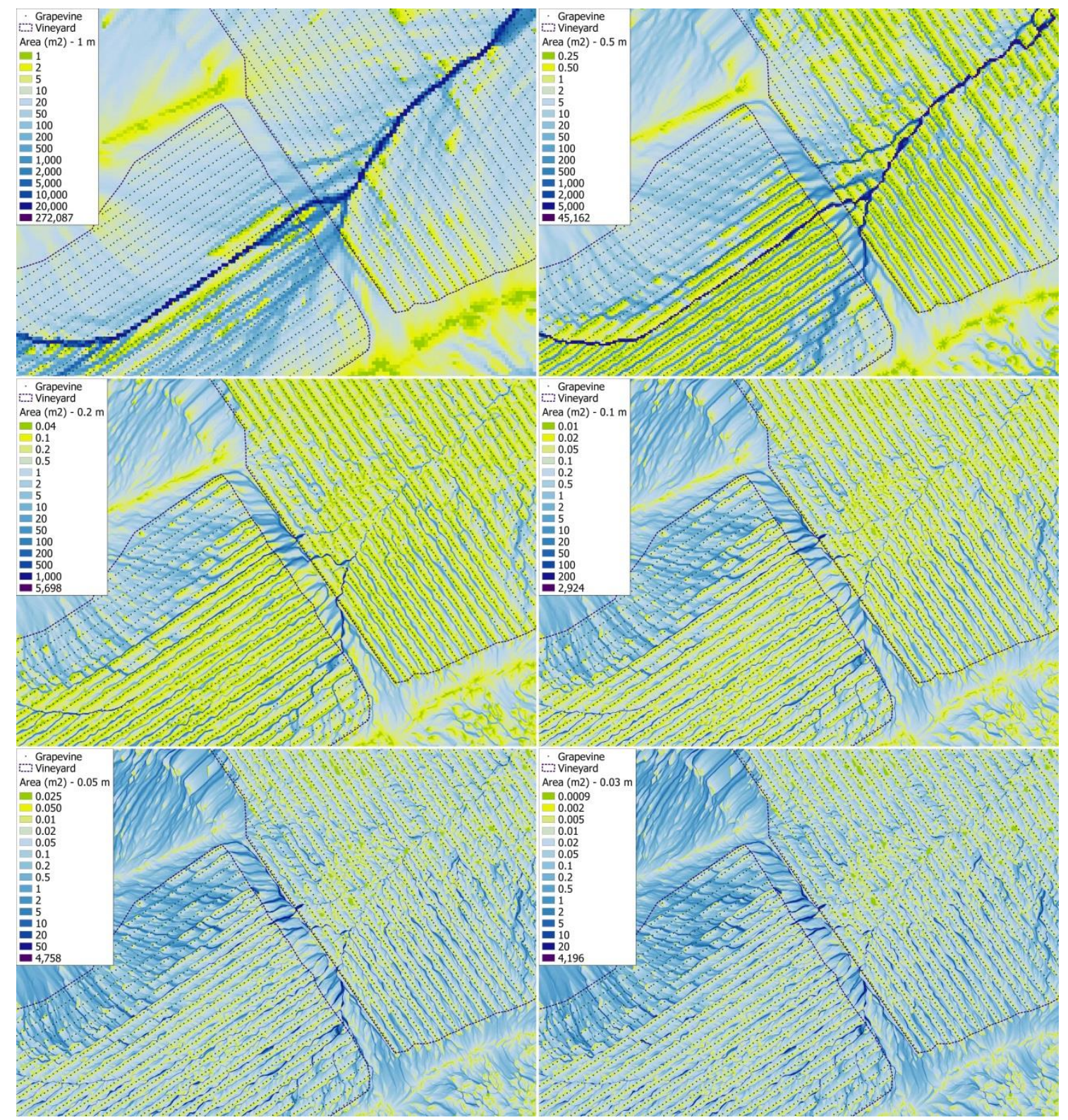

Figure 3. Detailed maps of flow accumulation within the vineyards derived at the six DEM resolutions. 

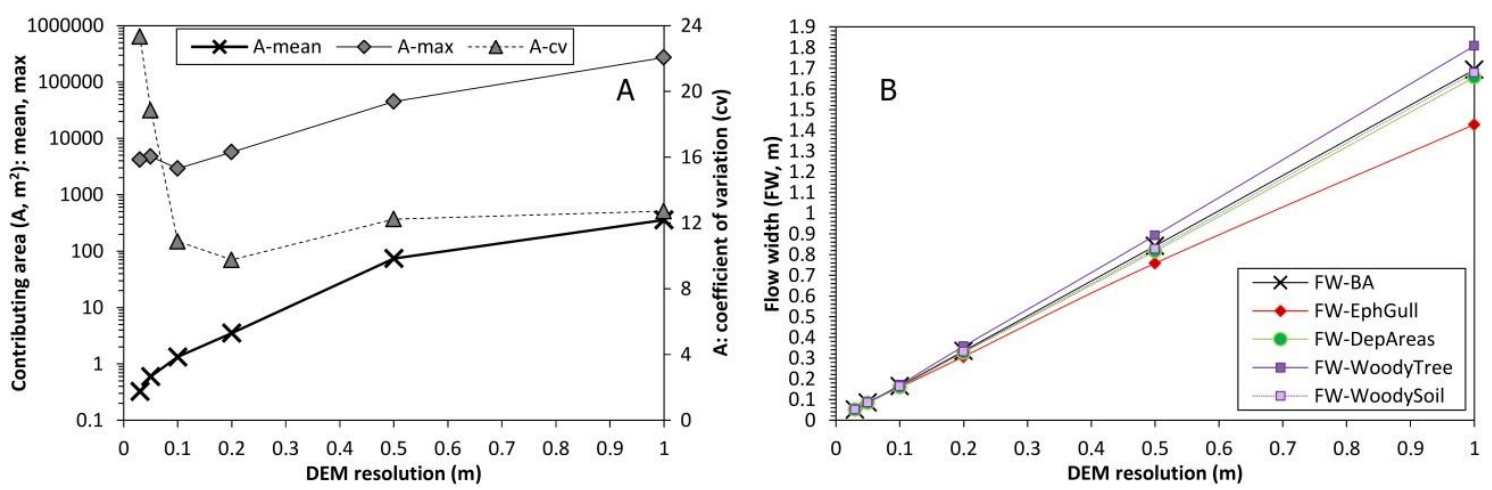

Figure 4. (a) Contributing area $\left(A, \mathrm{~m}^{2}\right)$, and (b) flow width $(F W, \mathrm{~m})$ estimated at the six DEM resolutions, and in the whole study area (BA), the ephemeral gullies (EphGull), the depositional areas (DepAreas), and in the row and inter-row areas of the woody crops. The coefficient of variation (cv) of $A$ is included. 


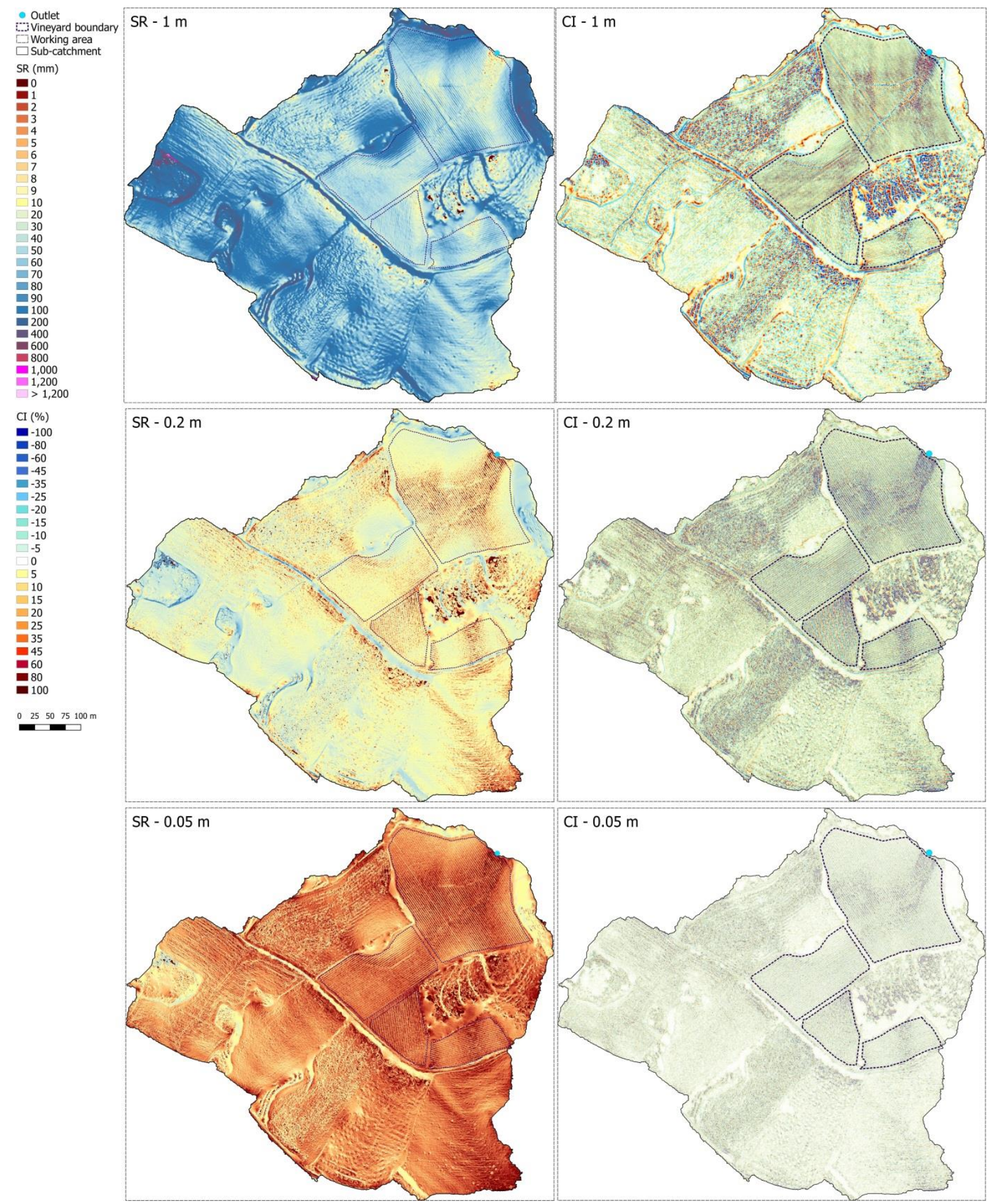

Figure 5. Maps of soil roughness $(S R, \mathrm{~mm})$ and convergence index $(C l, \%)$ at resolutions of $1,0.2$ and $0.05 \mathrm{~m}$. 


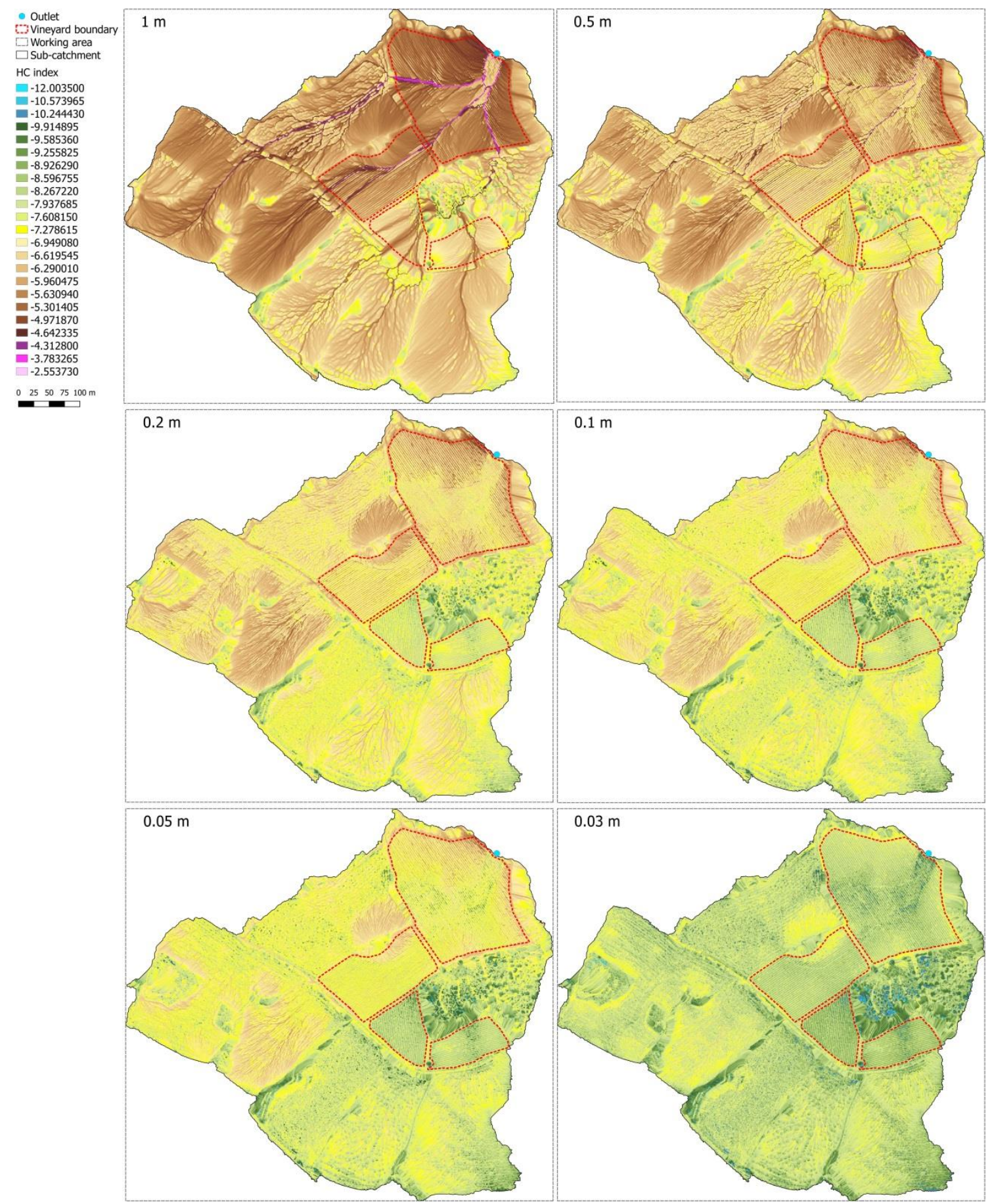

Figure 6. Maps of the $I C$ at the six spatial resolutions and before value normalisation. 

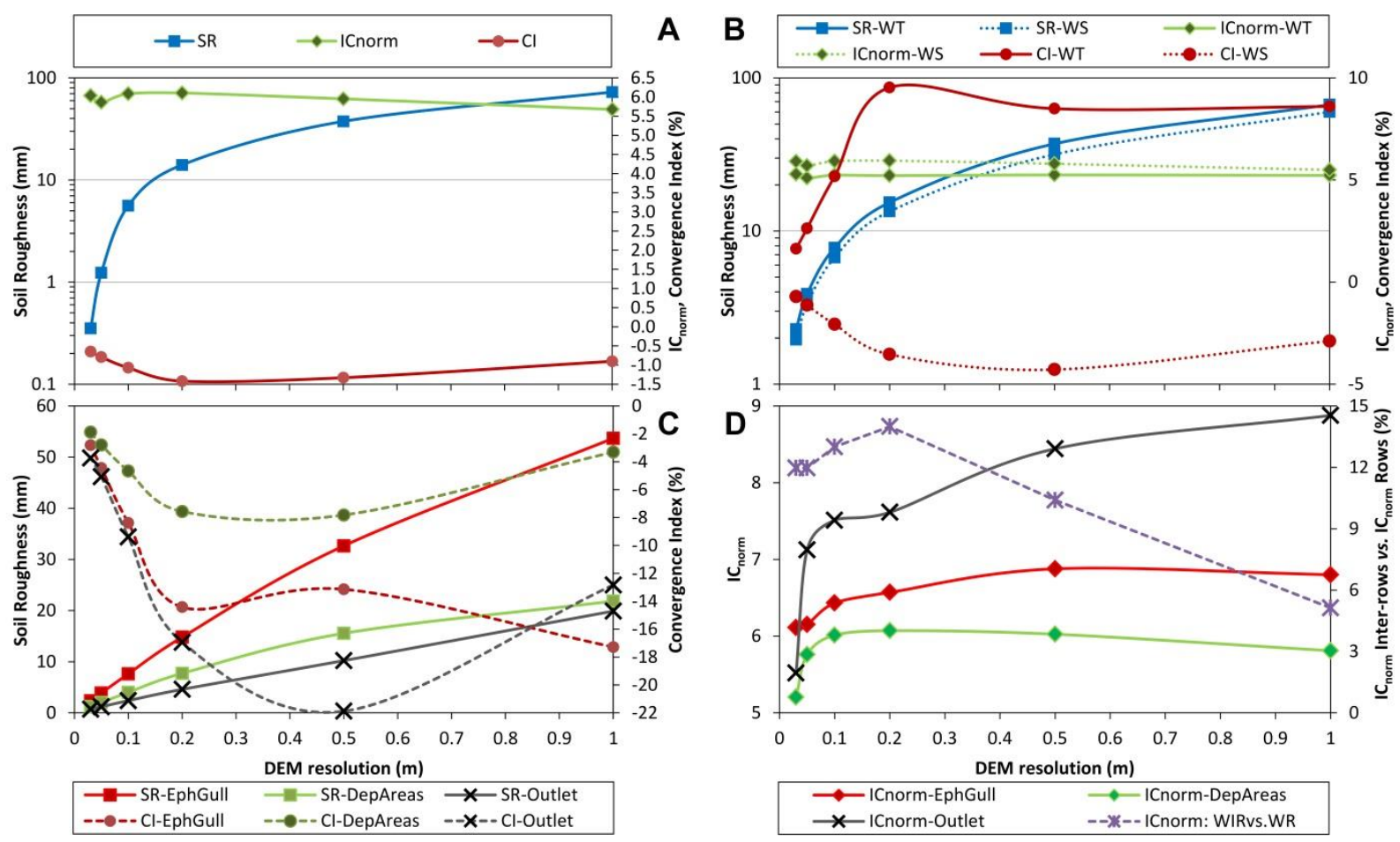

Figure 7. Mean values of soil roughness $(S R)$, convergence index $(C I)$ and normalised $I C\left(I C_{\text {norm }}\right)$ at the six DEM resolutions, and at a sub-catchment (BA) scale (a), within the woody crops (b) and in the main geomorphic features ( $c$ and d). WT: trees in the woody crops; WS: soil and inter-row area in the woody crops. 


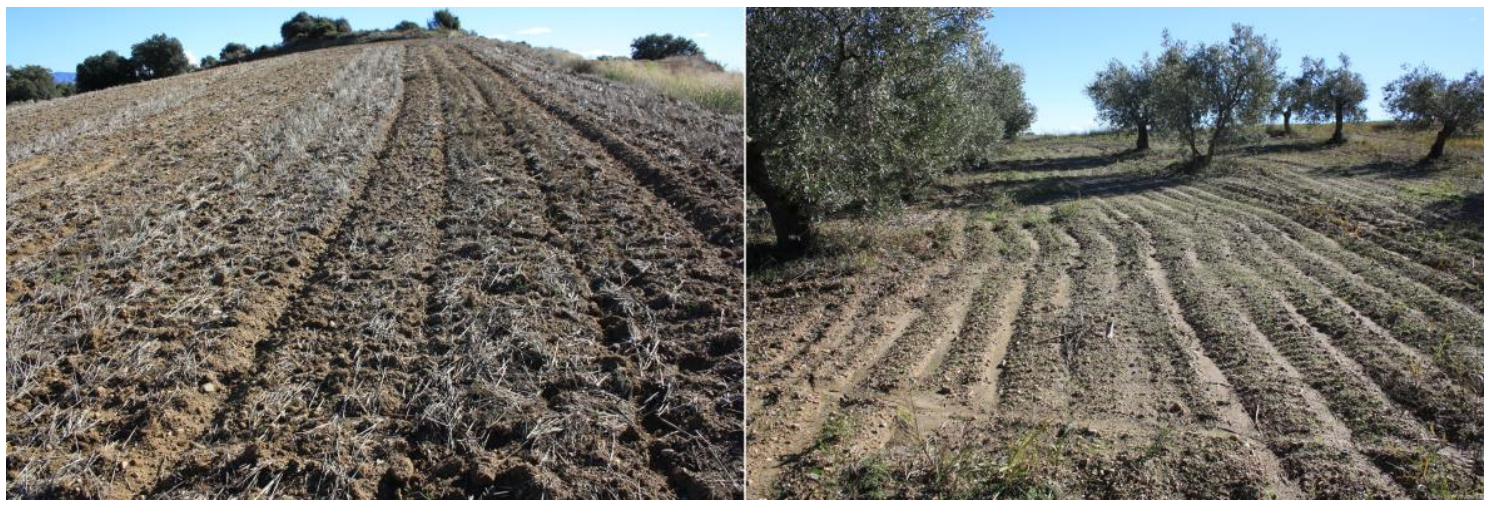

Supplementary Figure 1. Winter soil surface conditions in (a) the cereal fields and (b) the commercial olive grove. 


\section{Ground control points}

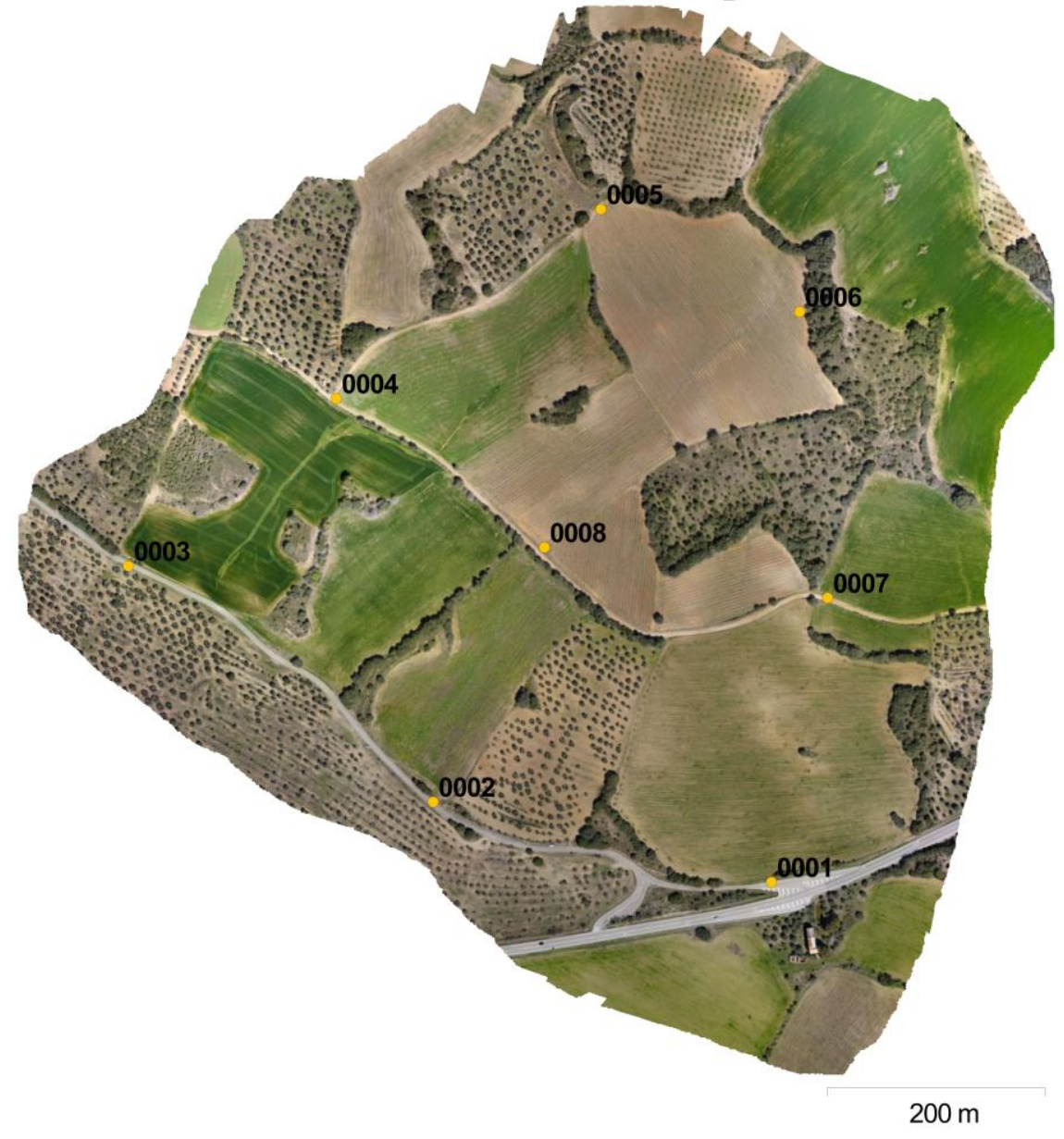

\begin{tabular}{|l|l|l|l|l|l|}
\hline Name & XY error $(\mathbf{m})$ & Error in Z $\mathbf{( m )}$ & Error $(\mathbf{m})$ & Projections & Error (pix) \\
\hline 0001 & 0.00358395 & -0.00142351 & 0.0038563 & 16 & 0.085 \\
\hline 0002 & 0.00382949 & 0.00103291 & 0.00396635 & 9 & 0.073 \\
\hline 0003 & 0.00482966 & 0.000186542 & 0.00483326 & 9 & 0.066 \\
\hline 0004 & 0.0132314 & -0.000682693 & 0.013249 & 12 & 0.069 \\
\hline 0005 & 0.00269047 & -0.00143117 & 0.00304744 & 10 & 0.063 \\
\hline 0006 & 0.00204588 & 0.00201859 & 0.00287408 & 14 & 0.038 \\
\hline 0007 & 0.00463694 & 0.000469602 & 0.00466066 & 16 & 0.053 \\
\hline 0008 & 0.00571438 & 0.000154304 & 0.00571647 & 13 & 0.072 \\
\hline RMS & $\mathbf{0 . 0 0 6 0 3 6 2}$ & $\mathbf{0 . 0 0 1 1 1 5 8 8}$ & $\mathbf{0 . 0 0 6 1 3 8 4 8}$ & & $\mathbf{0 . 0 6 6}$ \\
\hline
\end{tabular}

Supplementary Figure 2. Location of the eight ground control points used to correct the images obtained with the drone. Values of the horizontal and vertical accuracy of georeferencing are presented. 


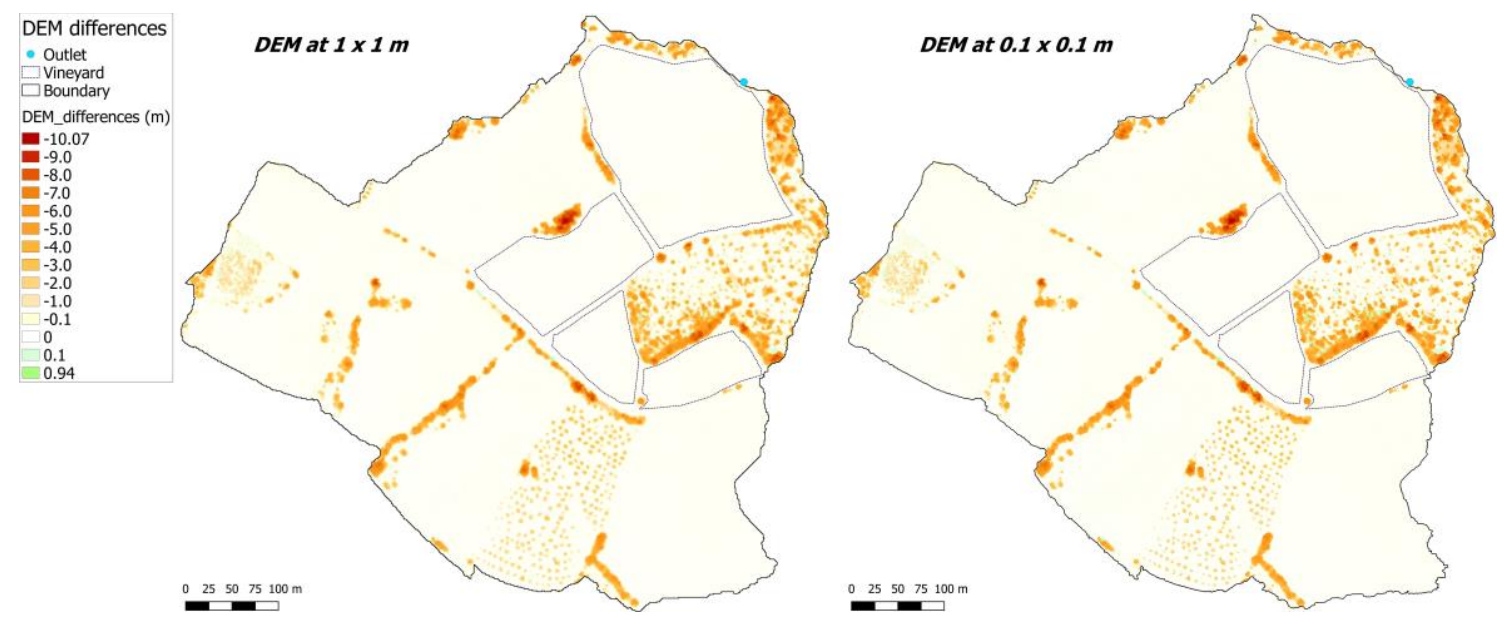

Supplementary Figure 3. Differences in the cell elevation after vegetation point removal in the DEMs at

(a) 1 and (b) $0.1 \mathrm{~m}$. 